\title{
Top-down estimates of biomass burning emissions of black carbon in the Western United States
}

\author{
Y. H. Mao ${ }^{1}$, Q. B. Li ${ }^{1,2}$, D. Chen ${ }^{1,2, *}$, L. Zhang ${ }^{1,2, * *}$, W.-M. Hao ${ }^{3}$, and K.-N. Liou ${ }^{1,2}$ \\ ${ }^{1}$ Department of Atmospheric and Oceanic Sciences, University of California, Los Angeles, CA 90095, USA \\ ${ }^{2}$ Joint Institute for Regional Earth System Science and Engineering, University of California, Los Angeles, \\ CA 90095, USA \\ ${ }^{3}$ Fire Sciences Laboratory, US Forest Service, Missoula, MT 59808, USA \\ * now at: National Center for Atmospheric Research, Boulder, CO 80307, USA \\ *** now at: Department of Mechanical Engineering, University of Colorado Boulder, Boulder, CO 80302, USA
}

Correspondence to: Q. B. Li (qli@atmos.ucla.edu)

Received: 27 February 2013 - Published in Atmos. Chem. Phys. Discuss.: 30 October 2013

Revised: 4 May 2014 - Accepted: 19 May 2014 - Published: 16 July 2014

\begin{abstract}
We estimate biomass burning and anthropogenic emissions of black carbon (BC) in the western US for MayOctober 2006 by inverting surface BC concentrations from the Interagency Monitoring of PROtected Visual Environment (IMPROVE) network using a global chemical transport model. We first use active fire counts from the Moderate Resolution Imaging Spectroradiometer (MODIS) to improve the spatiotemporal distributions of the biomass burning BC emissions from the Global Fire Emissions Database (GFEDv2). The adjustment primarily shifts emissions from late to middle and early summer (a $33 \%$ decrease in September-October and a $56 \%$ increase in June-August) and leads to appreciable increases in modeled surface BC concentrations in early and middle summer, especially at the 1-2 and $2-3 \mathrm{~km}$ altitude ranges. We then conduct analytical inversions at both $2^{\circ} \times 2.5^{\circ}$ and $0.5^{\circ} \times 0.667^{\circ}$ (nested over North America) horizontal resolutions. The a posteriori biomass burning BC emissions for July-September are $31.7 \mathrm{Gg}$ at $2^{\circ} \times 2.5^{\circ}$ (an increase by a factor of 4.7 ) and $19.2 \mathrm{Gg}$ at $0.5^{\circ} \times 0.667^{\circ}$ (an increase by a factor of 2.8 ). The inversion results are rather sensitive to model resolution. The a posteriori biomass burning emissions at the two model resolutions differ by a factor of $\sim 6$ in California and the Southwest and by a factor of 2 in the Pacific Northwest. The corresponding a posteriori anthropogenic $\mathrm{BC}$ emissions are $9.1 \mathrm{Gg}$ at $2^{\circ} \times 2.5^{\circ}$ (a decrease of $48 \%$ ) and $11.2 \mathrm{Gg}$ at $0.5^{\circ} \times 0.667^{\circ}$ (a decrease of $36 \%$ ). Simulated surface BC concentrations with the a posteriori emissions capture the ob-
\end{abstract}

served major fire episodes at most sites and the substantial enhancements at the $1-2$ and $2-3 \mathrm{~km}$ altitude ranges. The a posteriori emissions also lead to large bias reductions (by $\sim 30 \%$ on average at both model resolutions) in modeled surface BC concentrations and significantly better agreement with observations (increases in Taylor skill scores of $95 \%$ at $2^{\circ} \times 2.5^{\circ}$ and $42 \%$ at $0.5^{\circ} \times 0.667^{\circ}$.

\section{Introduction}

Black carbon (BC), as a component of fine particulate matter, has deleterious effects on human health (e.g., Anenberg et al., 2011, 2012; Smith et al., 2009). BC is also known as the agent to cause both degraded air quality (e.g., Anenberg et al., 2011, 2012) and warming due to its strong absorption of solar radiation (e.g., Ramanathan and Carmichael, 2008; Horvath, 1993). BC thus has considerable impacts on global climate (Fuglestvedt et al., 2010; Shindell et al., 2008; Levy II et al., 2008; Reddy et al., 2007; IPCC, 2007; Jacobson, 2001, 2004). BC deposited on snow and ice can significantly decrease the surface albedo (Warren and Wiscombe, 1980) and quicken surface melt (e.g., Flanner et al., 2007, 2009; Hansen and Nazarenko, 2004; Zwally et al., 2002). BC thus has a significant contribution to the observed rapid glacier retreats (Painter et al., 2013; Xu et al., 2009). Because of its shorter lifetime relative to long lived greenhouse gases such as carbon dioxide, $\mathrm{BC}$ shows a much stronger regional 
warming effect and its reduction may provide an efficient solution to mitigate near-term climate change and to improve air quality and human health simultaneously (Bond et al., 2013; Shindell et al., 2012; Kopp and Mauzerall, 2010; Ramana et al., 2010; Jacobson, 2002, 2010; Bond and Sun, 2005; Hansen et al., 2005).

The transport and subsequent deposition of $\mathrm{BC}$ is known to impact the regional climate and hydrological cycle in the western US mountain ranges. Mountain snowmelt accounts for over $70 \%$ of the annual stream flows in this region (Qian et al., 2009). Qian et al. (2009) showed that the deposition of $\mathrm{BC}$ on snow over the western US mountain ranges reduced snow accumulation in winter, snowmelt in spring, and runoff between April and June. The ongoing and most severe drought on record during the last 5 decades in California (e.g., Mirchi et al., 2013) and the dwindling water level of the Colorado River (e.g., Vano et al., 2013) both add even more urgency to better understand the sources, transport, and deposition of $\mathrm{BC}$ in the western US mountain ranges.

The uncertainty in current $\mathrm{BC}$ emission estimates ranges from at least $\pm 50 \%$ on global scales to a factor of $2-5$ on regional scales (Ramanathan and Carmichael, 2008; Streets et al., 2001, 2003). The uncertainty of biomass burning BC emissions in the western US is equally large, not only in the absolute magnitudes of fire emissions but also in the timing and location of fires (Mao et al., 2011). Part of the large uncertainty stems from estimates of burned area and fuel load (Langmann et al., 2009), especially of small fires, including agricultural burning (Randerson et al., 2012). Giglio et al. $(2006,2010)$ have shown that small fires can lead to high relative errors of $50-100 \%$ in the burned area estimates. The uncertainty is likely because of the lack of detection of small fires in the burned area algorithms (Randerson et al., 2012; van der Werf et al., 2010; McCarty et al., 2009; Roy and Boschetti, 2009; Korontzi et al., 2006). In addition, the increases of fire frequency, fire season length, and annual burned area observed in the western US in recent decades have been linked to the warm climate (Peterson and Marcinkowski, 2014; Westerling et al., 2006). The annual burned area in the western US is also projected to increase by $25-125 \%$ in the 2050 s relative to the present under future warming (Yue et al., 2013; Spracklen et al., 2009). It is therefore conceivable that, biomass burning emissions as an important source to $\mathrm{BC}$ will have an even larger contribution to BC in the western US in the 21 st century.

Understanding the distributions of a chemical species in the atmosphere depends on the information of the emissions. Bottom-up emission estimates generally rely on emission factors using socioeconomic, energy, land use, or environmental data (Bond et al., 2007, 2013; Lu et al., 2011). In recent years, there has been an increasing emphasis on the use of inverse methods to characterize the temporal and spatial variability of emissions. Top-down inversions have been widely used for estimating emission fluxes of long-lived trace gases such as carbon dioxide (e.g., Pickett-Heaps et al., 2011;
Chevallier et al., 2007; Gloor et al., 1999), methane (e.g., Wecht et al., 2012; Meirink et al., 2008; Hein et al., 1997), and carbon monoxide based on observations from surface stations (e.g., Bergamaschi et al., 2000; Kasibhatla et al., 2002), aircraft (e.g., Palmer et al., 2003, 2006), and satellites (Jiang et al., 2011, 2013; Jones et al., 2009; Stavrakou and Müller, 2006; Arellano et al., 2004, 2006), when the atmospheric concentrations are linearly or weakly non-linearly dependent on their emissions (Müller and Stavrakou, 2005). Top-down inversions, by nature, are a way to examine the consistency of model results with observations. It is important to note that the abovementioned studies have consistently demonstrated that the bottom-up and top-down approaches are not mutually exclusive. Improving estimate of emissions is inherently an iterative process and it is imperative to optimally integrate both bottom-up and top-down approaches.

Several studies have used multiple regressions to estimate annual mean sources of primary carbonaceous aerosols over the US (Park et al., 2003) and in China (Wang et al., 2013; Fu et al., 2012). The goal of the present study is to improve our understanding of sources of BC in the western US mountain ranges, with a particular focus on biomass burning emissions during May-October 2006, broadly encompassing the fire season in the region. We first improve the spatial distributions and the seasonal and interannual variations of $\mathrm{BC}$ emissions using high spatial resolution active fire counts. We then apply top-down inversions of surface BC concentration measurements using a global 3-dimensional chemical transport model (CTM). We briefly describe the observations in Sect. 2 and the model in Sect. 3. We then discuss in Sect. 4 improvements to the spatiotemporal distributions of biomass burning emissions of BC. In Sect. 5, we describe the analytical inversion method. The inversion results and discussions are presented in Sect. 6. We give a summary and draw conclusions in Sect. 7.

\section{Observations}

\subsection{IMPROVE}

The Interagency Monitoring of PROtected Visual Environment (IMPROVE) surface network in the US was created for the protection of visibility in Class I remote areas (Malm et al., 1994). Long-term measurements of aerosols with chemical species including BC are available from the network since 1987 (data available at http://vista.cira.colostate.edu/ improve/). We use surface BC concentration data for 2006 from 69 sites across the western US (Fig. 1 and Supplement Table S1). These are mostly remote sites located predominantly in national parks. $\mathrm{BC}$ mass concentration is measured by the thermal optical reflectance (TOR) combustion method based on the preferential oxidation of organic carbon (OC) and $\mathrm{BC}$ at different temperatures (Chow et al., 2004). The 


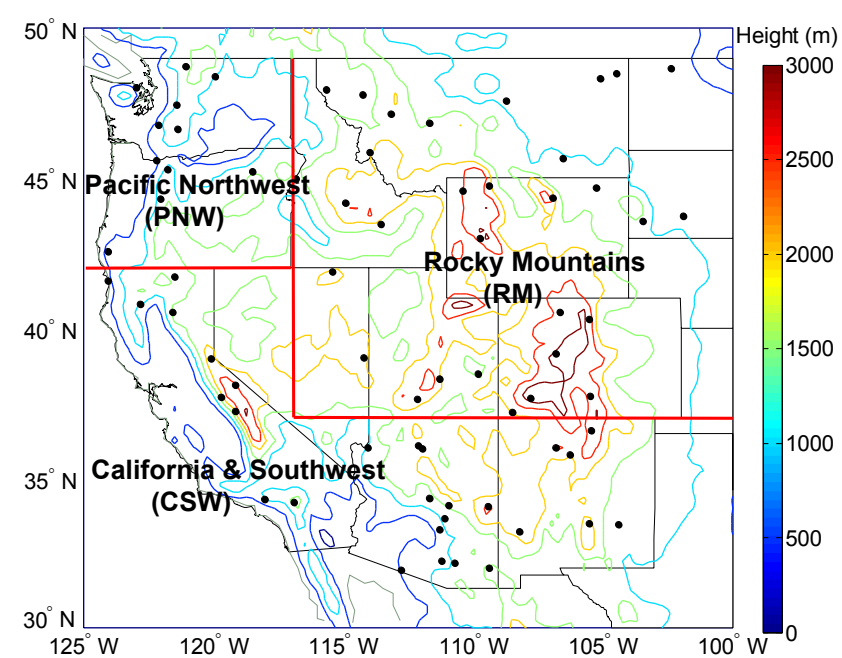

Figure 1. The 69 IMPROVE sites (black dots) used in this study (data available at http://vista.cira.colostate.edu/improve/). Also shown are the three biomass burning regions used to define the state vector of the inversion analyses: the Rocky Mountains (RM), California and the Southwest (CSW), and the Pacific Northwest (PNW). Terrain heights are indicated by color contours.

uncertainties of the method are difficult to quantify (Park et al., 2003; Chow et al., 1993). The measurements are made every 3 days and $24 \mathrm{~h}$ averages are reported. Previously, sulfate and nitrate aerosol measurements from the IMPROVE network have been used to constrain their precursor emissions using the GEOS-Chem CTM and its adjoint (Henze et al., 2009).

\subsection{MODIS}

The Moderate Resolution Imaging Spectroradiometer (MODIS) active fire product (available at $\mathrm{ftp}$ //fuoco.geog.umd.edu) detects fires in $1 \mathrm{~km}$ pixels that are burning at the time of overpass under relatively cloud-free conditions using a contextual algorithm (Giglio et al., 2003). The detection utilizes the strong emission of mid-infrared radiation from fires and applies thresholds to the observed middle-infrared and thermal-infrared brightness temperatures. The algorithm examines each pixel of the MODIS swath, and ultimately assigns to each one of the following classes: missing data, cloud, water, non-fire, fire, or unknown. We use here MODIS active fire counts at the spatial resolution of $0.5^{\circ} \times 0.5^{\circ}$ and a temporal resolution of 8 days.

\section{Model description and simulations}

We apply the GEOS-Chem global 3-dimensional CTM (Bey et al., 2001, with many updates thenceforth) to analyze IMPROVE surface BC observations. GEOS-Chem is driven by assimilated meteorological observations from the Goddard
Earth Observing System (GEOS) of the NASA Global Modeling and Assimilation Office (GMAO). Here we use GEOSChem version 8-03-02 (available at http://geos-chem.org) driven by GEOS-5 meteorological data with a temporal resolution of $6 \mathrm{~h}$ ( $3 \mathrm{~h}$ for surface variables and mixing depths), horizontal resolutions of $2^{\circ}$ (latitude) $\times 2.5^{\circ}$ (longitude) and $0.5^{\circ}$ (latitude) $\times 0.667^{\circ}$ (longitude), and 47 hybrid eta levels in the vertical from the surface to $0.01 \mathrm{hPa}$. The lowest model levels are centered at approximately 60,200,300, 450, $600,700,850,1000,1150,1300,1450,1600$, and $1800 \mathrm{~m}$ above the local surface. GEOS-Chem simulations at the finer horizontal resolution are typically nested over a continentalscale domain within the global domain. Lateral boundary conditions for the nested-grid simulations are archived from a global simulation. The nested-grid simulation employs the same meteorology, dynamics, and chemistry as the global simulation, thus allows for consistent propagation of features from the global to the nested domain via one-way nesting.

Tracer advection is computed every 15 minutes with a flux-form semi-Lagrangian method (Lin and Rood, 1996). Tracer moist convection is computed using GEOS convective, entrainment, and detrainment mass fluxes as described by Allen et al. (1996a, b). The deep convection in GEOS-5 is parameterized using the relaxed Arakawa-Schubert scheme (Moorthi and Suarez, 1992; Arakawa and Schubert, 1974), and the shallow convection treatment follows Hack (1994). Simulation of aerosol wet and dry deposition follows Liu et al. (2001). Wet deposition includes contributions from scavenging in convective updrafts, rainout from convective anvils, and rainout and washout from large-scale precipitation. Dry deposition of aerosols uses a resistance-in-series model (Walcek et al., 1986) dependent on local surface type and meteorological conditions.

GEOS-Chem simulation of carbonaceous aerosols has been reported previously by Park et al. (2003). Eighty percent of $\mathrm{BC}$ and $50 \%$ of OC emitted from primary sources are assumed to be hydrophobic, and hydrophobic aerosols become hydrophilic with an e-folding time of 1.2 days (Park et al., 2003; Chin et al., 2002; Cooke et al., 1999). BC aerosols in the model are assumed to be externally mixed. Global anthropogenic (fossil fuel and biofuel) emissions of $\mathrm{BC}$ are based upon Bond et al. (2007) with imposed seasonality following Park et al. (2003). Biomass burning emissions of BC are from the Global Fire Emissions Database version 2 (GFEDv2) emissions with an 8-day temporal resolution (Randerson et al., 2007; van der Werf et al., 2006). We include for comparison BC emissions from GFEDv3 (van der Werf et al., 2010) and the Fire Locating and Monitoring of Burning Emissions (FLAMBE) inventory (Reid et al., 2009).

GFEDv2 was derived using satellite observations including active fire counts and burned areas in conjunction with a biogeochemical model (Randerson et al., 2007; van der Werf et al., 2006). Burned area was derived using monthly $1^{\circ} \times 1^{\circ}$ active fire and $500 \mathrm{~m}$ burned area data from MODIS (Giglio et al., 2006). Total carbon emissions were then calculated 
as the product of burned area, fuel load, and combustion completeness. Fuel load depends on vegetation type, climate, soil type, and time passed since the last fire, while combustion completeness (the fraction of the available fuel combusted during a fire) depends on the type of fire, fuel (e.g., stems, leaves, and litter) and its moisture content (Langmann et al., 2009). The Carnegie-Ames-Stanford Approach (CASA) biogeochemical model was used to estimate combustion completeness as well as fuel load and the associated spatial variability (van der Werf et al., 2006, and references therein). $\mathrm{BC}$ emissions were then derived from the total carbon emissions and BC emission factors. GFEDv3 includes several updates over GFEDv2: a finer spatial resolution $\left(0.5^{\circ}\right)$, a better mapping method in estimating $500 \mathrm{~m}$ global burned area, a local (in lieu of regional) regression in producing the indirect, active-fire based estimates of burned area, and an improved CASA model.

FLAMBE provides carbon emissions at a $1^{\circ} \times 1^{\circ}$ spatial resolution and hourly temporal resolution based on both MODIS and Geostationary Operational Environmental Satellites (GOES) fire counts. Hourly emissions are available from 2005. Fire pixel detections and subpixel burning characterizations were computed based on the operational NOAA/NESDIS GOES Wildfire Automated Biomass Burning Algorithm (WF_ABBA) for most of the Western Hemisphere. For the rest of the globe, the near real time University of Maryland/NASA MODIS fire products from Terra and Aqua were used. The Advanced Very High Resolution Radiometer (AVHRR) Global Land Cover Characteristics (GLCC) data (v2.0) was used to assign surface emissivity and to screen for false alarms. Based on the thermal anomaly and fire radiative power in a subpixel fire, FLAMBE provides hourly burned areas and carbon emissions. Following Fisher et al. (2010), we calculate BC emissions using emission factors from Andreae and Merlet (2001).

For computational expediency, we conduct GEOS-Chem "offline" simulations of carbonaceous aerosols following Mao et al. (2011). We conduct simulations for 2006 at both $2^{\circ} \times 2.5^{\circ}$ and $0.5^{\circ} \times 0.667^{\circ}$ resolutions. The first 3 months are used for initialization and we focus our analysis on May through October. The finer resolution is nested over North America $\left(40-140^{\circ} \mathrm{W}\right.$ longitudes, $10-70^{\circ} \mathrm{N}$ latitudes, cf. Fig. 1 in Wang et al., 2004). Wang et al. (2004) reported the first nested-grid GEOS-Chem simulations of carbon monoxide over North America. Chen et al. (2009) provided a detailed description of the one-way nesting in the model.

Model results are sampled at the corresponding locations of the IMPROVE sites. IMPROVE observations are $24 \mathrm{~h}$ averages sampled every 3 days and we sample the model accordingly. It is known that comparing localized observations such as the IMPROVE data with model results that are representative of a much larger area is inherently problematic (Mao et al., 2011; Fairlie et al., 2007). Furthermore, many of the IMPROVE sites are at high elevations and the associated upslope flow is difficult to represent in a coarse-resolution model.

\section{Spatiotemporal distributions of biomass burning BC emissions}

Mao et al. (2011) pointed out that the GFEDv2 inventory not only underestimated the magnitude but also inadequately captured the temporal (and presumably spatial) distribution of biomass burning emissions in the western US (WUS, defined hereinafter as $30-50^{\circ} \mathrm{N}, 100-125^{\circ} \mathrm{W}$ for clarity). Ample evidence has suggested that the root cause of these deficiencies was likely the lack of detection of small fires, for example, prescribed and agricultural burning (e.g., Randerson et al., 2012; Giglio et al., 2010). Randerson et al. (2012) pointed out that current global burned area products largely missed small fires because such fires were typically well below the detection limit of the burned area algorithms. For instance, GFEDv2 burned area was derived from MODIS $500 \mathrm{~m}$ surface reflectance, suited for detecting large fires with fire scars greater than $500 \mathrm{~m}$ (Giglio et al., 2006, 2010). Active fire data has long been used as a proxy for burned area due to the lack of long-term global burned area data (Giglio et al., 2006, 2010). MODIS active fire data, based on thermal anomalies, allows for the detection of fires that are an order of magnitude smaller in size than those detected by MODIS $500 \mathrm{~m}$ surface reflectance. MODIS active fire data thus preserves detailed aspects of the spatial distribution and seasonality of burning (Randerson et al., 2012, and references therein).

Here we use MODIS active fire counts from 2005-2007 to improve the spatiotemporal distribution of GFEDv2 BC emissions in North America. The adjusted emissions will be the a priori for the inversions presented hereinafter. There are large uncertainties in relating fire counts to actual burned area because of inadequate temporal sampling, variability in fuel conditions and cloud cover, differences in fire behavior, and issues related to spatial resolution (Giglio et al., 2006; Kasischke et al., 2003). We choose the 3 -year period in part to minimize such uncertainties. We adjust the emissions for three zones: boreal North America, temperate North America, and Mexico and Central America, following the geographic regions defined in the GFED inventory (Giglio et al., 2006, 2010). We first sum up for each zone the monthly carbon emissions and MODIS active fire counts from 2005-2007. We then redistribute the emissions according to the ratio of the active fire counts for each 8-day period within each grid box $\left(0.5^{\circ} \times 0.5^{\circ}\right)$ to the total fire counts. We note that the adjusted GFEDv2 emissions have the same total emissions as the original GFEDv2. We would like to point out that, fuel loading and combustion completeness are also basic factors to derive emissions and have large spatial and temporal variations. The emission adjustment presented here therefore would introduce some uncertainties without considering 


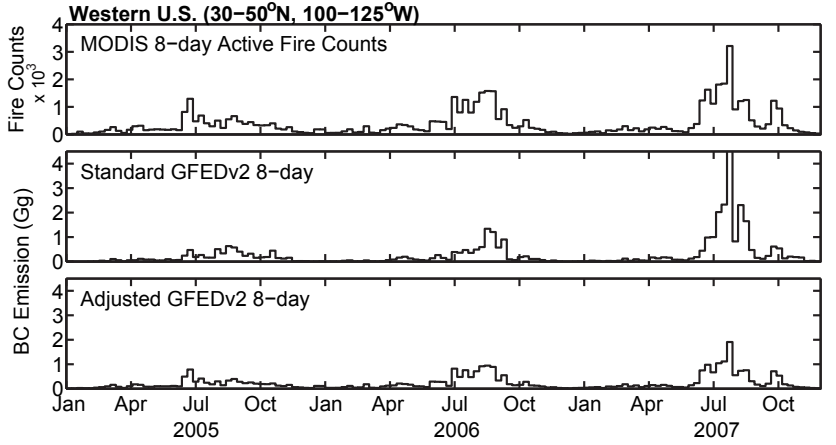

Figure 2. MODIS active fire counts (top panel) and the GFEDv2 biomass burning emissions of $\mathrm{BC}$ (middle and bottom panels) summed over the western US from 2005 to 2007. The emissions before (middle panel) and after (bottom panel) applying spatiotemporal adjustments based on the active fire counts (see text for details on the adjustments) are both shown. Data shown here has an 8-day temporal resolution. MODIS active fire counts data are available at ftp://fuoco.geog.umd.edu. GFED data are available at http://daac. ornl.gov/VEGETATION/guides/global_fire_emissions_v2.1.html.

these issues. We make another emission adjustment with the same calculation method but using daily active fire counts and carbon emissions only in the WUS for 2006 to partially measure these uncertainties. The resulting emissions are essentially the same as the former adjusted emissions and we thus focus our analysis on the former adjusted emissions hereinafter.

Figure 2 shows the active fire counts and the biomass burning $\mathrm{BC}$ emissions (before and after the adjustments), summed over the WUS, from 2005 to 2007. Of the 3 years, 2006 is a relatively large fire year. Fire seasons in the WUS typically last from late June to October even November, as evident in both the fire counts and the emissions. The fire season in 2006 is from July to September primarily. The adjustment largely shifts emissions from late to middle and early summer. Take 2006 for example, the adjustment results in a $33 \%$ decrease in September-October and a $56 \%$ increase in June-August. The spatial distributions of monthly BC emissions for July-September 2006, before and after the adjustments, are shown in Fig. 3. There are significant increases in the agricultural areas in August and September, e.g., Columbia River Basin in Washington, Oregon, and Idaho, and Snake River Basin in Idaho. These increases reflect improved spatial allocation of biomass burning emissions using MODIS active fire counts, which now presumably pick up (small) agricultural burning. The adjusted emissions track spatiotemporally MODIS active fire counts (Fig. 3a), as expected.

The spatiotemporal shift of the emissions manifests in higher $\mathrm{BC}$ concentrations in some regions and lower concentrations in others. Figure 4 compares modeled surface $\mathrm{BC}$ concentrations against observations for May-October 2006 at six IMPROVE sites. Model results are from simu-
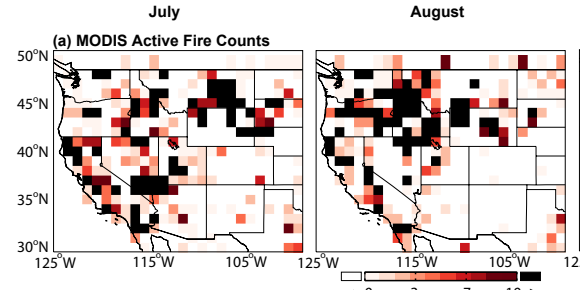

September 2006
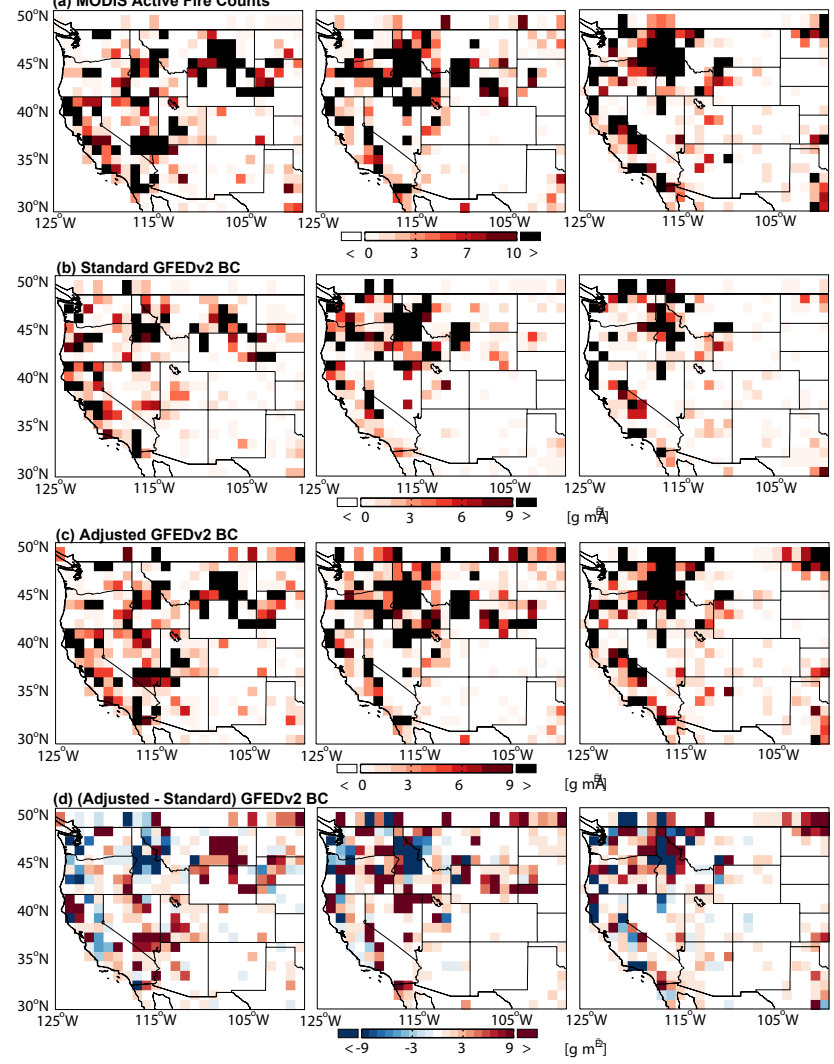

Figure 3. Monthly MODIS active fire counts and biomass burning emissions of BC (unit: $\mathrm{g} \mathrm{m}^{-2}$ ) in the western US for July, August, and September 2006, respectively: (a) MODIS active fire counts, (b) standard GFEDv2 BC emissions, (c) GFEDv2 BC emissions adjusted spatiotemporally based on the active fire counts (see text for details on the adjustments), and (d) the difference between (c) and (b).

lations at $2^{\circ} \times 2.5^{\circ}$ or $0.5^{\circ} \times 0.667^{\circ}$ horizontal resolutions . There are substantial increases of surface BC concentrations (up to $\sim 100 \%$ ) after the emission adjustment, at Bend, MT $\left(47.6^{\circ} \mathrm{N}, 108.7^{\circ} \mathrm{W}, 0.89 \mathrm{~km}\right)$ and North Cheyenne, MT $\left(45.7^{\circ} \mathrm{N}, 106.6^{\circ} \mathrm{W}, 1.28 \mathrm{~km}\right)$ in early and middle summer, while concentrations are appreciably lower (up to $\sim 10 \%$ at $\left.2^{\circ} \times 2.5^{\circ}\right)$ at Starkey, OR $\left(45.2^{\circ} \mathrm{N}, 118.5^{\circ} \mathrm{W}, 1.26 \mathrm{~km}\right)$ and Mt. Cabinet, MT $\left(48.0^{\circ} \mathrm{N}, 115.7^{\circ} \mathrm{W}, 1.44 \mathrm{~km}\right)$ in September and October. The resulting changes to modeled surface BC concentration are largely consistent between the two resolutions but are considerably more pronounced at $2^{\circ} \times 2.5^{\circ}$ than at $0.5^{\circ} \times 0.667^{\circ}$ at Starkey and Mt. Cabinet.

Figure 5 shows modeled vs. observed surface BC concentrations averaged for sites at the $0-1,1-2,2-3$, and $3-4 \mathrm{~km}$ altitude ranges for May-October 2006. The adjusted emissions lead to small yet significant relative enhancements of model surface $\mathrm{BC}$ concentrations (up to $\sim 0.05 \mu \mathrm{g} \mathrm{m}^{-3}$ ) at both model resolutions from late June to August. These enhancements are particularly evident at the $1-2$ and $2-3 \mathrm{~km}$ 

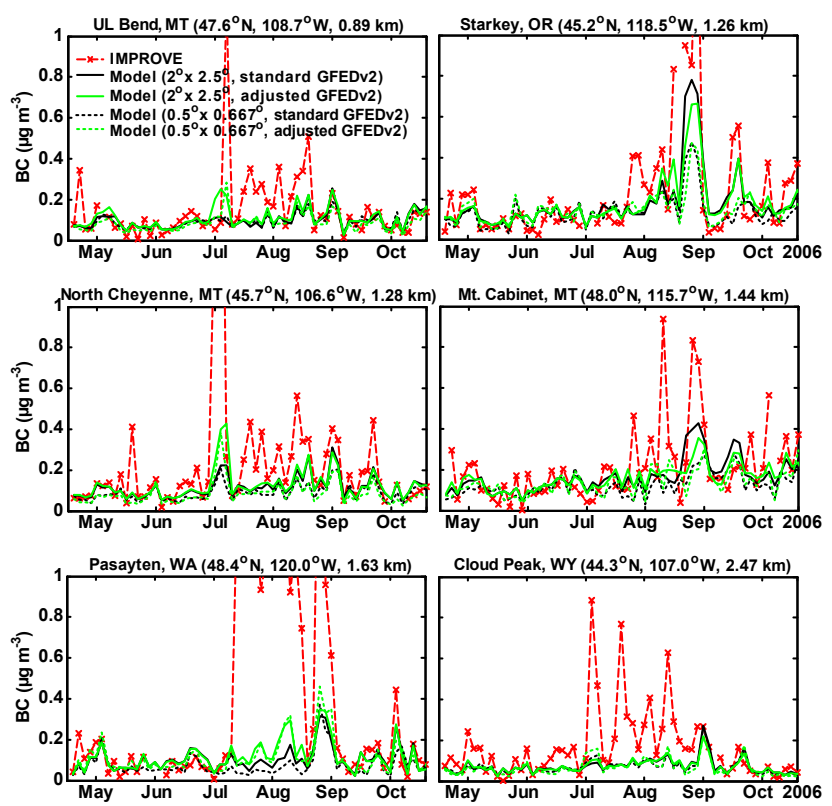

Figure 4. Observed (red line) and simulated $24 \mathrm{~h}$ average surface BC concentrations $\left(\mu \mathrm{g} \mathrm{m}^{-3}\right)$ at six IMPROVE sites for MayOctober 2006. Values shown are $24 \mathrm{~h}$ averages for every 3 days. Model results are from simulations at $2^{\circ} \times 2.5^{\circ}$ (solid line) and $0.5^{\circ} \times 0.667^{\circ}$ (dotted line) horizontal resolutions and with the standard (black line) and the adjusted (green line; see Figs. 2 and 3 ) GFEDv2 emissions. Model results are sampled at the time and location of IMPROVE observations.

altitude ranges at $0.5^{\circ} \times 0.667^{\circ}$ and yet insignificant at $3-$ $4 \mathrm{~km}$ sites. The adjustments also provide better agreement with the observations at sites below $1 \mathrm{~km}$, especially at $0.5^{\circ} \times 0.667^{\circ}$. The adjustment to the emissions reduces the median model bias by $64 \%$ at $0.5^{\circ} \times 0.667^{\circ}$ but has little to no effect on the model bias at $2^{\circ} \times 2.5^{\circ}$ (Fig. 6).

\section{Analytical solution to the inverse problem}

Analytical inversion methods are applicable for linear or weakly non-linear conditions between emissions and atmospheric concentrations (Müller and Stavrakou, 2005). Previous studies have shown that the GEOS-Chem simulations of $\mathrm{BC}$ were linear with respect to $\mathrm{BC}$ emissions (e.g., Wang et al. 2011, 2013; Kopacz et al., 2011). Considering the problem of inferring emissions (state vector $\boldsymbol{X}$ ) given observations (observation vector $\boldsymbol{Y}$ ) with error $\varepsilon$, the two are related via a forward model $F$ as follows (Rodgers, 2000):

$\boldsymbol{Y}=F(\boldsymbol{X})+\varepsilon$,

where $\boldsymbol{X}$ is monthly BC emissions (Fig. 1) in the present study, $\boldsymbol{Y}$ the $24 \mathrm{~h}$ average BC surface concentrations (Fig. 1 and Supplement Table S1), and $F$ the GEOS-Chem model. Based on Bayes' theorem and the assumption of Gaussian error distributions (Rodgers, 2000), the optimal or maximum
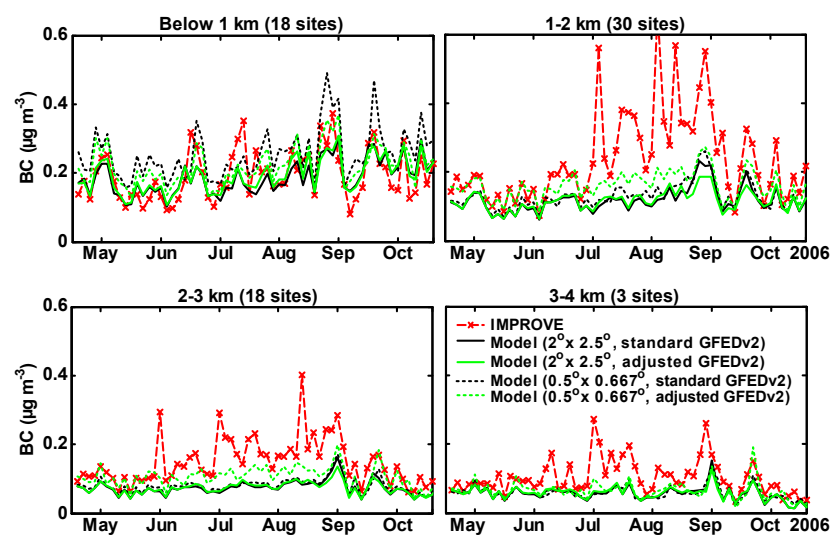

Figure 5. Observed (red line) and simulated $24 \mathrm{~h}$ average surface BC concentrations $\left(\mu \mathrm{g} \mathrm{m}^{-3}\right)$ at IMPROVE sites for May-October 2006, averaged for four altitude ranges: below $1 \mathrm{~km}$ (averages at 18 sites), 1-2 km (averages at 30 sites), 2-3 km (averages at 18 sites), and above $3 \mathrm{~km}$ (averages at three sites). Model results are from simulations at $2^{\circ} \times 2.5^{\circ}$ (solid line) and $0.5^{\circ} \times 0.667^{\circ}$ (dotted line) horizontal resolutions and with the standard (black line) and the adjusted (green line; see Figs. 2 and 3) GFEDv2 emissions.

a posteriori (MAP) solution to Eq. (1) is equivalent to finding the minimum of an error-weighted least squares cost function $J(X)$ (Rodgers, 2000),

$J(\boldsymbol{X})=(\boldsymbol{Y}-\mathbf{K} \boldsymbol{X}){ }^{\mathbf{T}} \mathbf{S}_{\Sigma}^{-1}(\boldsymbol{Y}-\mathbf{K} \boldsymbol{X})+\left(\boldsymbol{X}-\boldsymbol{X}_{\mathrm{a}}\right)^{\mathbf{T}} \mathbf{S}_{\mathrm{a}}^{-1}\left(\boldsymbol{X}-\boldsymbol{X}_{\mathrm{a}}\right)$,

where $\boldsymbol{X}_{\mathrm{a}}$ and $\mathbf{S}_{\mathrm{a}}$ are the a priori emissions and the associated error covariance, $\mathbf{S}_{\Sigma}$ the observational error covariance, and $\mathbf{K}=\nabla_{\boldsymbol{X}} F$ the Jacobian matrix. Minimization of $J(\boldsymbol{X})$ yields

$\hat{\boldsymbol{X}}=\boldsymbol{X}_{\mathrm{a}}+\left(\mathbf{K}^{\mathbf{T}} \mathbf{S}_{\Sigma}^{-1} \mathbf{K}+\mathbf{S}_{\mathrm{a}}^{-1}\right)^{-1} \mathbf{K}^{\mathbf{T}} \mathbf{S}_{\Sigma}^{-1}\left(\boldsymbol{Y}-\mathbf{K} \boldsymbol{X}_{\mathrm{a}}\right)$

$\hat{\mathbf{S}}=\left(\mathbf{K}^{\mathbf{T}} \mathbf{S}_{\Sigma}^{-1} \mathbf{K}+\mathbf{S}_{\mathrm{a}}^{-1}\right)^{-1}=(\mathbf{I}-\mathbf{A}) \mathbf{S}_{\mathrm{a}}(\mathbf{I}-\mathbf{A})^{\mathbf{T}}+\mathbf{G} \mathbf{S}_{\Sigma} \mathbf{G}^{\mathbf{T}}$,

Where $\hat{\boldsymbol{X}}$ is the a posteriori emissions, $\hat{\mathbf{S}}$ the a posteriori error covariance, $\mathbf{I}$ the identity matrix, $\mathbf{G}=\frac{\partial \hat{X}}{\partial Y}$ the gain matrix (the sensitivity of the retrieval to the observations), and $\mathbf{A}=\frac{\partial \hat{\boldsymbol{X}}}{\partial \boldsymbol{X}}=\mathbf{G K}=\mathbf{I}-\hat{\mathbf{S}} \mathbf{S}_{\mathrm{a}}^{-1}$ the averaging kernel matrix. In a successful inversion, the cost function should be of the same order as the number of observations, provided that errors are properly specified (Palmer et al., 2003).

The matrix of averaging kernel and the number of degrees of freedom for signal (DOFs) are useful metrics for inspecting the ability of the observing system to uniquely constrain individual element of the state vector (Kasibhatla et al., 2002). The averaging kernel matrix represents the sensitivity of the a posteriori estimates to the unknown true state. Averaging kernels peaking at their own state vector element denote a well constrained source, which shows the inversion system has enough information to constrain the source categories independently. DOFs is the trace of the averaging 

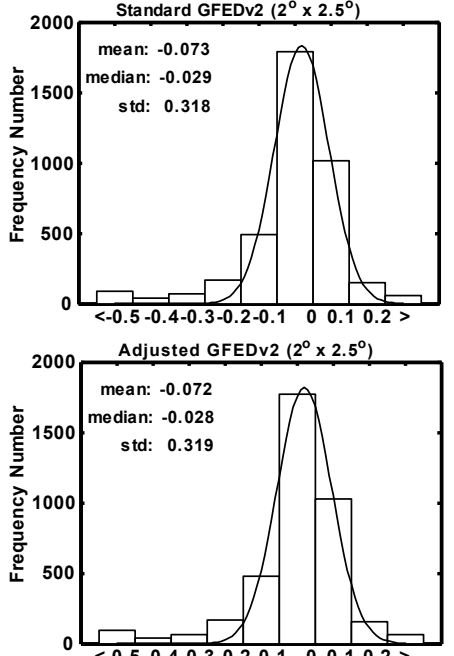

A posteriori $\left(2^{\circ} \times 2.5^{\circ}\right)$
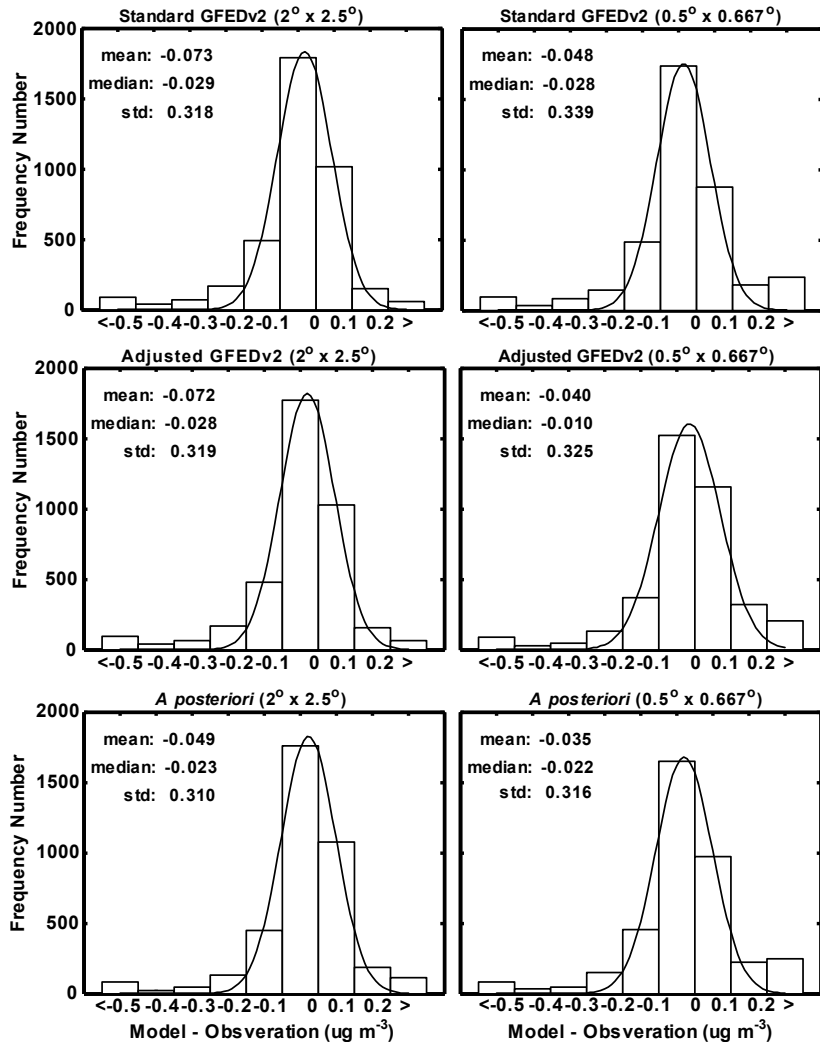

Adjusted GFEDv2 $\left(0.5^{\circ} \times 0.667^{\circ}\right)$

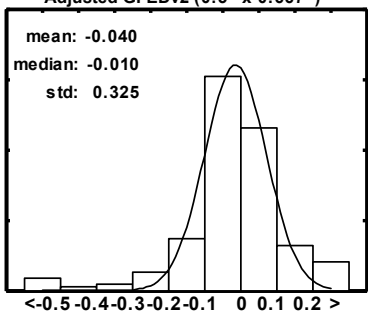

A posteriori $\left(0.5^{\circ} \times 0.667^{\circ}\right)$

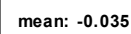

median: $-\mathbf{0 . 0 2 2}$

std: 0.31

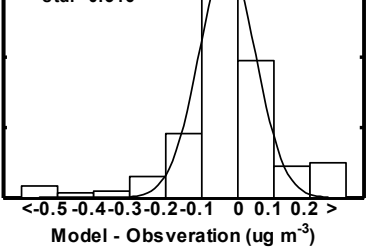

Figure 6. Number frequency of model bias for May-October 2006. Model bias is defined as the difference between simulated and observed $24 \mathrm{~h}$ average surface BC concentrations $\left(\mu \mathrm{g} \mathrm{m}^{-3}\right)$ at IMPROVE sites. Model results are from simulations at $2^{\circ} \times 2.5^{\circ}$ and $0.5^{\circ} \times 0.667^{\circ}$ horizontal resolutions and with the standard, the adjusted (see Figs. 2 and 3), and a posteriori emissions. Also shown are the mean, median, standard deviation, and fitted Gaussian distribution curve of the biases.

kernel matrix (Rodgers, 2000). The number of pieces of information from a perfect inversion system is expected to be the size of the state vector. Following Jaffe et al. (2008), we initially include in the state vector five regions of biomass burning: the northern Rocky Mountains, the southern Rocky Mountains, California, the Southwest, and the Pacific Northwest. Upon examining the averaging kernel and DOFs, we find that the inversion system is unable to distinguish the biomass burning from the northern vs. the southern Rockies. Therefore, we lump these two regions. We also lump California and the Southwest for the same reason. Our analyses show that biomass burning emissions in the WUS account for $\sim 85 \%$ of the total biomass burning contribution to surface $\mathrm{BC}$ in the region for May-October 2006. The corresponding contribution from Canadian fire is $\sim 7 \%$. We thus define a four-component state vector (Fig. 1): biomass burning emissions in the Rockies (BBRM), California and the Southwest (BBCSW), and the Pacific Northwest (BBPNW), and anthropogenic emissions in the WUS (ANTHWUS).
We assume a $50 \%$ uncertainty for the anthropogenic BC emissions in North America, within the 30-60\% range suggested by Bond et al. (2004). GFEDv2 fuel loading has an uncertainty of $22 \%$ for woody biomass and $44 \%$ for herbaceous biomass, while combustion completeness has an uncertainty of $\sim 50 \%$ (van der Werf et al., 2010). GFEDv2 burned area has an uncertainty of 10-40\% for large fires and $50-100 \%$ for small fires (Giglio et al., 2006). BC emission factor has an uncertainty of $\sim 40 \%$ for savanna, grasslands, and extra-tropical forest (Andreae and Merlet, 2001). Mao et al. (2011) suggested that GFEDv2 BC emissions were likely biased low by a factor of 2-3 in the WUS. We assume for separate inversions presented here uncertainty of 200, 300, or $500 \%$ for biomass burning emissions of BC in the WUS. We assume that the a priori errors are spatially uncorrelated.

The observation error includes contributions from predominantly model transport error, representation error, and measurement error (Heald et al., 2004). We estimate the transport error by computing the variance of the relative difference between the observations and the corresponding model BC concentrations, following Palmer et al. (2003) and Heald et al. (2004). The mean model bias, as diagnosed by the mean relative difference, is a result of errors in the a priori sources, while the variance of the relative residual error is chiefly because of errors in the transport. The resulting model transport error is $\sim 20 \%$, consistent with previous studies (Kopacz et al., 2009; Heald et al., 2004; Palmer et al., 2003). Jiang et al. (2011) used the differences in GEOSChem simulated carbon monoxide distributions with two different GEOS meteorological fields (GEOS-3 vs. GEOS-4) as an alternative measure of model transport error. They found that such transport error introduced an error of up to $20 \%$ on the source estimates. The representation error describes the mismatch between model results and the corresponding observations. This error arises because model results are averages over a large model grid scale (e.g., $\sim 200 \times 250 \mathrm{~km}^{2}$ at $2^{\circ} \times 2.5^{\circ}$ ), while as observations are typically point measurements. Palmer et al. (2003) estimated a representation error (for carbon monoxide) of 5-10\% of observations for GEOSChem simulations at $2^{\circ} \times 2.5^{\circ}$. Their estimate was based upon aircraft measurements, mostly $1 \mathrm{~km}$ over the ocean, and corresponding model simulations over the western Pacific. It is likely that the representation error in the WUS should be larger than 5-10\% merely because of the complex terrain, which is more difficult (relative to remote oceans) to resolve in coarse-resolution models. We thus assume a 5-10\% representation error as a lower limit in the analyses presented here. We further assume a measurement error of $5-10 \%$ for IMPROVE BC measurements. The total observation error is set at 30 or $50 \%$.

Inspection of the averaging kernels and DOFs shows that an a priori biomass burning error of $500 \%$ and an observation error of $30 \%$ provide the best overall inversion results, with higher resolution in the averaging kernels (Fig. 7) and highest values of DOFs (Table 1). The averaging kernels at the two 

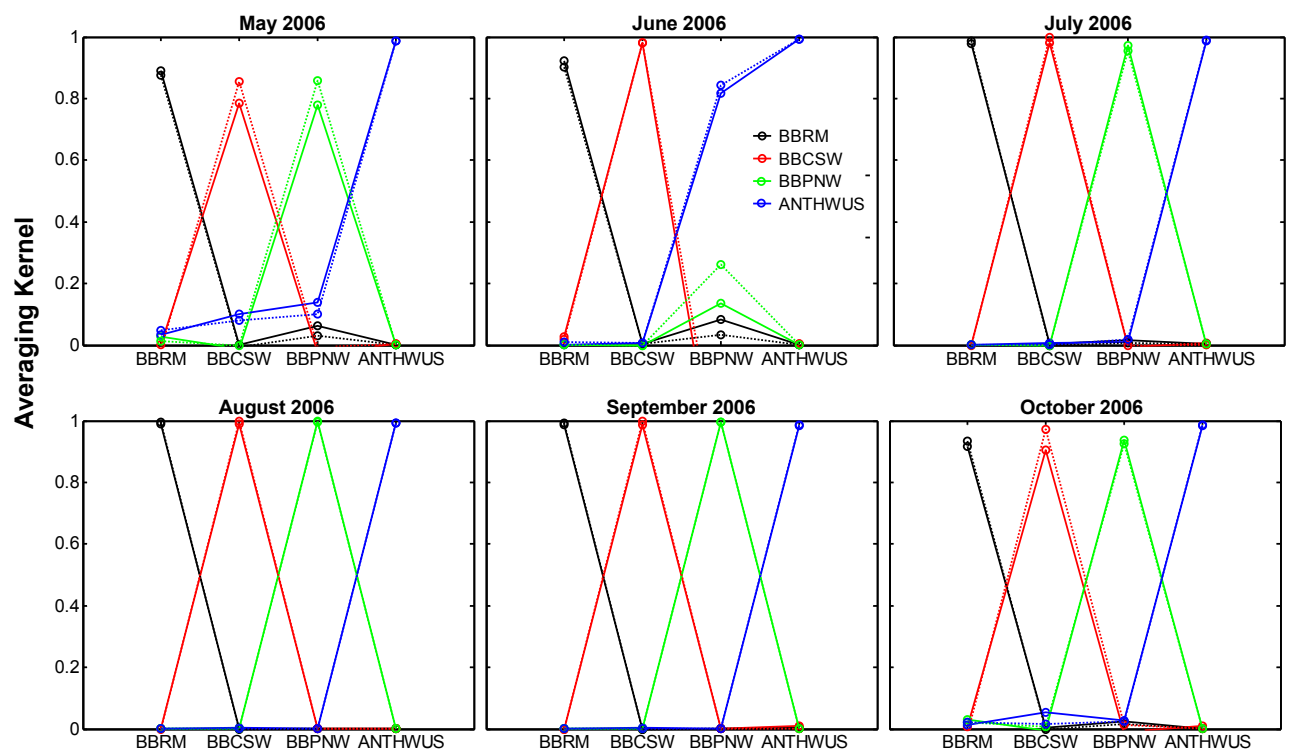

Figure 7. The averaging kernels for inversions (May-October 2006) of BC emissions in the western US, with each line corresponding to an emission source or source region: biomass burning emissions in the Rockies (BBRM, black line), biomass burning emissions in California and the Southwest (BBCSW, red line), biomass burning emissions in the Pacific Northwest (BBPNW, green line), and anthropogenic emissions in the western US (ANTHWUS, blue line). Results here are from simulations at $2^{\circ} \times 2.5^{\circ}$ (solid line) and $0.5^{\circ} \times 0.667^{\circ}$ (dotted line) horizontal resolutions and with best set of error characterizations (30\% for observations and $500 \%$ for biomass burning emissions; bottom two rows in Table 1).

Table 1. Number of degrees of freedom for signal (DOFs) for inversions (May-October 2006) using different error characterizations and at $2^{\circ} \times 2.5^{\circ}$ and $0.5^{\circ} \times 0.667^{\circ}$ horizontal resolutions.

\begin{tabular}{llllllll}
\hline & Error & \multicolumn{6}{c}{ DOFs } \\
\cline { 2 - 8 } & specification & May & Jun & Jul & Aug & Sept & Oct \\
\hline & $\mathbf{S}_{\Sigma}=50 \%$ & & & & & & \\
& $\mathbf{S}_{\mathrm{a} B B}=300 \%$ & 2.36 & 2.68 & 3.60 & 3.85 & 3.81 & 2.99 \\
& $\mathbf{S}_{\Sigma}=30 \%$ & & & & & & \\
$2^{\circ} \times 2.5^{\circ}$ & $\mathbf{S}_{\mathrm{a} B} \mathrm{BB}=300 \%$ & 2.87 & 2.80 & 3.80 & 3.93 & 3.91 & 3.41 \\
& $\mathbf{S}_{\Sigma}=30 \%$ \\
& $\mathbf{S}_{\mathrm{a} B} \mathrm{BB}=200 \%$ & 2.30 & 2.56 & 3.61 & 3.85 & 3.82 & 2.95 \\
& $\mathbf{S}_{\Sigma}=30 \%$ & & & & & & \\
& $\mathbf{S}_{\mathrm{a} B \mathrm{BB}}=500 \%$ & 3.44 & 3.03 & 3.92 & 3.97 & 3.96 & 3.74 \\
\hline $0.5^{\circ} \times 0.667^{\circ}$ & $\mathbf{S}_{\Sigma}=30 \%$ & & & & & & \\
\hline & $\mathbf{S}_{\mathrm{a} B B}=500 \%$ & 3.57 & 3.14 & 3.93 & 3.98 & 3.97 & 3.82 \\
\hline
\end{tabular}

model resolutions are essentially indistinguishable. Overall the retrievals are slightly better constrained at $0.5^{\circ} \times 0.667^{\circ}$ than at $2^{\circ} \times 2.5^{\circ}$, as evident in the higher DOFs. Figure 7 shows that the inversion system is able to constrain each element of the state vector independently, especially during July to September and to a lesser degree in October. However, the system has insufficient information to distinguish anthropogenic from biomass burning BC emissions in May and June.
The cost function provides yet another metric for appraising the quality of an inversion. The inversions presented here see large cost function reductions $\left(42 \%\right.$ at $2^{\circ} \times 2.5^{\circ}$ and $38 \%$ at $\left.0.5^{\circ} \times 0.667^{\circ}\right)$. In addition, the cost function values are of the same order as the number of observations $(\sim 690)$. Palmer et al. (2003) showed that the value of the cost function in a successful inversion should be of the same order as the number of observations, provided that the errors are properly specified. 

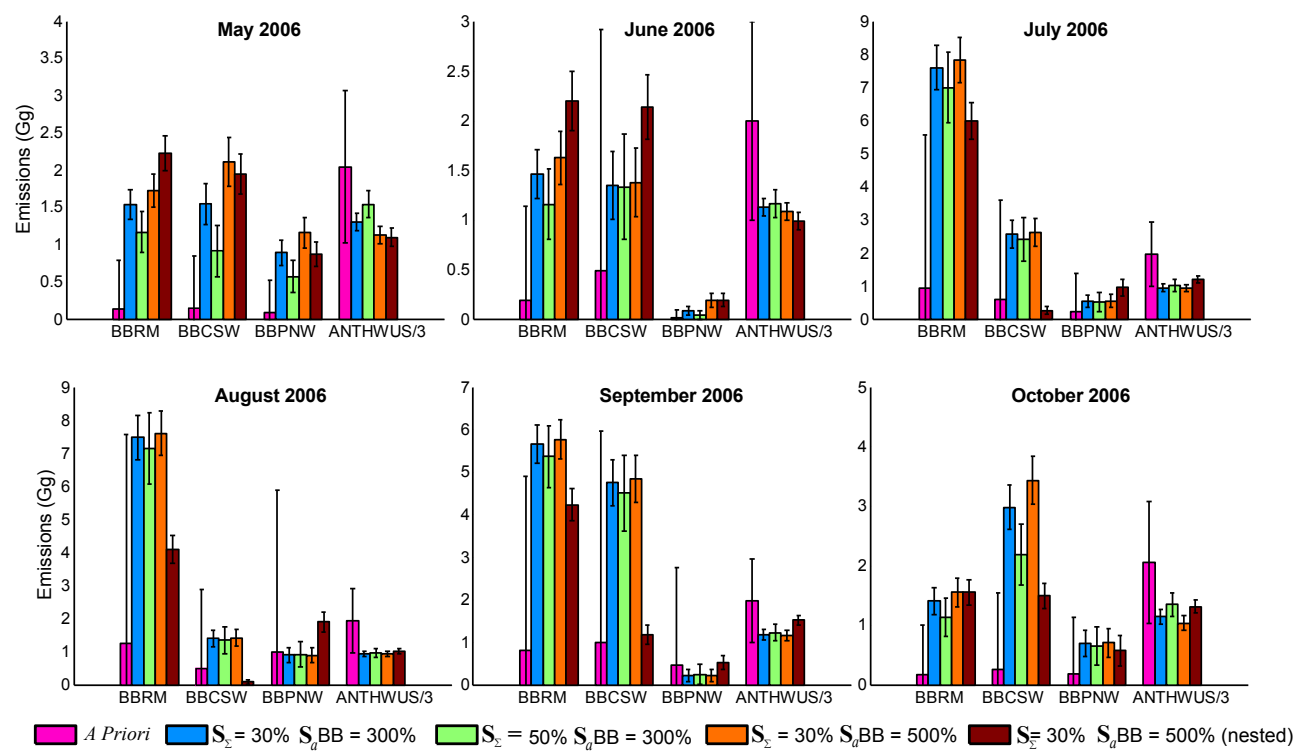

Figure 8. Monthly BC emissions in the western US for May-October 2006: a priori BC emissions (pink); a posteriori emissions of biomass burning BC from the Rockies (BBRM), from California and the Southwest (BBCSW), and from the Pacific Northwest (BBPNW), and a posteriori emissions of anthropogenic BC from the western US (ANTHWUS). The a posteriori emissions are from inversions at $2^{\circ} \times 2.5^{\circ}$ (blue, green, orange) and $0.5^{\circ} \times 0.667^{\circ}$ (red) horizontal resolutions, color-coded by error characterizations (see text for details). For the purpose of clarity, anthropogenic emissions are divided by 3 in the figures. Error bars represent estimated uncertainties of the emissions.

\section{Results and discussions}

\subsection{A posteriori estimates of $\mathrm{BC}$ emissions}

Figure 8 shows the a priori (i.e., adjusted GFEDv2, see Sect. 4) and the a posteriori estimates of monthly BC emissions in the WUS for May-October 2006. The anthropogenic emissions are divided by 3 in the figures, for the sake of clarity, because the anthropogenic emissions are considerably larger than biomass burning emissions. The a posteriori biomass burning emissions increase (by a factor of 3-5 on average) dramatically and consistently, while the a posteriori anthropogenic emissions decrease (by $\sim 50 \%$ ) substantially. The retrievals also largely reduce the uncertainties of the emissions by more than $50 \%$. An a priori biomass burning emissions error of $500 \%$ and an observational error of $30 \%$ provide the best overall inversion results, with larger reductions in uncertainties (Fig. 8), larger DOFs (Table 1), and better-resolved averaging kernels (Fig. 7). By the same metrics, the inversion results are appreciably better at $0.5^{\circ} \times 0.667^{\circ}$ than at $2^{\circ} \times 2.5^{\circ}$. As expected, model simulations with the former also result in better agreement with observations.

Table 2 presents the a priori and a posteriori monthly biomass burning and anthropogenic $\mathrm{BC}$ emissions in the WUS for May-October 2006. The a posteriori biomass burning $\mathrm{BC}$ emissions are $31.7 \mathrm{Gg}$ at $2^{\circ} \times 2.5^{\circ}$ (4.7 times the a priori) and $19.2 \mathrm{Gg}$ at $0.5^{\circ} \times 0.667^{\circ}$ (2.8 times the a priori) for July-September. The a posteriori biomass burning emissions show large regional and month-to-month differ- ences between the two model resolutions. For example, the a posteriori biomass burning emissions at $2^{\circ} \times 2.5^{\circ}$ for JulySeptember increase by factors of 7.0 in the Rockies and 4.3 in the CSW, relative to the corresponding a priori. The a posteriori biomass burning emissions in the WUS increase by factors of 6.3 (4.1) in July and 3.6 (2.2) in August at $2^{\circ} \times 2.5^{\circ}\left(0.5^{\circ} \times 0.667^{\circ}\right)$. The a posteriori anthropogenic BC emissions are $9.1 \mathrm{Gg}$ at $2^{\circ} \times 2.5^{\circ}$ (a $48 \%$ reduction relative to the a priori) and $11.2 \mathrm{Gg}$ at $0.5^{\circ} \times 0.667^{\circ}$ (a $36 \%$ reduction relative to the a priori) for July-September 2006. These decreases in anthropogenic BC emissions estimates are consistent with the findings by Rao and Somers (2010), who showed that BC emissions in the US had declined by $\sim 30 \%$ from 1990 to 2005 and were expected to decline by an additional $80 \%$ by 2030 . Murphy et al. (2011) have shown that observed BC concentrations from 50 IMPROVE sites decreased by more than $25 \%$ on average from 1990 to 2004, reflecting effective anthropogenic $\mathrm{BC}$ emission control in the US.

It is useful to compare biomass burning $\mathrm{BC}$ emissions in the WUS between the a priori, a posteriori, GFEDv3, and FLAMBE. The total BC emissions for 2006, however, are lower in GFEDv3 than in GFEDv2 (and the a priori emissions) (van der Werf et al., 2010). Here we focus on JulySeptember 2006. The emissions are $8 \%$ higher in GFEDv3 than in the a priori. These differences are largest in August $(20 \%)$ and September $2006(15 \%)$. GFEDv3 emissions are considerably lower than the a posteriori estimates at $2^{\circ} \times 2.5^{\circ}$ (by a factor of 4.4 ) and at $0.5^{\circ} \times 0.667^{\circ}$ (by a 
Table 2. Monthly biomass burning BC emissions from three regions (see Fig. 1) and anthropogenic BC emissions in the western US for MayOctober 2006 (unit: $\mathrm{Gg}$ ). A priori and a posteriori biomass burning emissions from inversions at $2^{\circ} \times 2.5^{\circ}$ and $0.5^{\circ} \times 0.667^{\circ}$ are shown. Also shown are the Global Fire Emissions Database version 3 (GFEDv3) and the Fire Locating and Monitoring of Burning Emissions (FLAMBE) for comparison.

\begin{tabular}{|c|c|c|c|c|c|c|c|c|}
\hline \multirow[t]{2}{*}{ Source region } & \multirow[t]{2}{*}{ Emissions } & \multicolumn{7}{|c|}{ BC Emissions (Gg), 2006} \\
\hline & & May & Jun & Jul & Aug & Sep & Oct & Jul-Sep total \\
\hline \multirow[t]{7}{*}{ BBRM } & A priori GFEDv2 & 0.13 & 0.19 & 0.93 & 1.26 & 0.82 & 0.17 & 3.01 \\
\hline & A posteriori & 1.72 & 1.62 & 7.83 & 7.60 & 5.77 & 1.55 & 21.20 \\
\hline & $\left(2^{\circ} \times 2.5^{\circ}\right)$ & $\left(0.22^{*}\right)$ & $(0.26)$ & $(0.69)$ & $(0.68)$ & $(0.46)$ & $(0.24)$ & $(1.82)$ \\
\hline & A posteriori & 2.23 & 2.20 & 5.99 & 4.08 & 4.23 & 1.55 & 14.30 \\
\hline & $\left(0.5^{\circ} \times 0.667^{\circ}\right)$ & $(0.23)$ & $(0.30)$ & $(0.56)$ & $(0.42)$ & $(0.38)$ & $(0.21)$ & $(1.36)$ \\
\hline & GFEDv3 & 0.00 & 0.12 & 0.61 & 1.47 & 0.73 & 0.05 & 2.81 \\
\hline & FLAMBE & 0.47 & 0.82 & 4.73 & 5.96 & 3.86 & 0.21 & 14.55 \\
\hline \multirow[t]{7}{*}{ BBCSW } & A priori GFEDv2 & 0.14 & 0.49 & 0.60 & 0.48 & 0.99 & 0.26 & 2.07 \\
\hline & A posteriori & 2.11 & 1.38 & 2.63 & 1.41 & 4.84 & 3.44 & 8.88 \\
\hline & $\left(2^{\circ} \times 2.5^{\circ}\right)$ & $(0.33)$ & $(0.35)$ & $(0.42)$ & $(0.25)$ & $(0.55)$ & $(0.40)$ & (1.23) \\
\hline & A posteriori & 1.95 & 2.14 & 0.26 & 0.08 & 1.17 & 1.50 & 1.51 \\
\hline & $\left(0.5^{\circ} \times 0.667^{\circ}\right)$ & $(0.27)$ & $(0.33)$ & $(0.12)$ & $(0.06)$ & $(0.23)$ & $(0.21)$ & $(0.41)$ \\
\hline & GFEDv3 & 0.02 & 0.30 & 0.49 & 0.48 & 1.31 & 0.11 & 2.28 \\
\hline & FLAMBE & 0.61 & 3.25 & 5.78 & 1.96 & 9.05 & 0.62 & 16.79 \\
\hline \multirow[t]{7}{*}{ BBPNW } & A priori GFEDv2 & 0.09 & 0.02 & 0.23 & 0.98 & 0.46 & 0.19 & 1.67 \\
\hline & A posteriori & 1.16 & 0.19 & 0.55 & 0.89 & 0.21 & 0.70 & 1.65 \\
\hline & $\left(2^{\circ} \times 2.5^{\circ}\right)$ & $(0.20)$ & $(0.07)$ & $(0.19)$ & $(0.23)$ & $(0.14)$ & $(0.24)$ & $(0.56)$ \\
\hline & A posteriori & 0.87 & 0.19 & 0.95 & 1.90 & 0.52 & 0.57 & 3.37 \\
\hline & $\left(0.5^{\circ} \times 0.667^{\circ}\right)$ & $(0.16)$ & $(0.07)$ & $(0.24)$ & $(0.30)$ & $(0.17)$ & $(0.26)$ & $(0.71)$ \\
\hline & GFEDv3 & 0.00 & 0.01 & 0.27 & 1.31 & 0.56 & 0.02 & 2.14 \\
\hline & FLAMBE & 0.26 & 0.28 & 2.35 & 3.97 & 2.40 & 0.29 & 8.72 \\
\hline \multirow[t]{7}{*}{ BBWUS } & A priori GFEDv2 & 0.36 & 0.70 & 1.76 & 2.72 & 2.27 & 0.62 & 6.75 \\
\hline & A posteriori & 4.99 & 3.19 & 11.01 & 9.90 & 10.82 & 5.69 & 31.73 \\
\hline & $\left(2^{\circ} \times 2.5^{\circ}\right)$ & $(0.75)$ & $(0.68)$ & $(1.30)$ & $(1.16)$ & (1.16) & $(0.88)$ & (3.61) \\
\hline & A posteriori & 5.05 & 4.53 & 7.20 & 6.06 & 5.92 & 3.62 & 19.18 \\
\hline & $\left(0.5^{\circ} \times 0.667^{\circ}\right)$ & $(0.66)$ & $(0.69)$ & $(0.92)$ & $(0.79)$ & $(0.77)$ & $(0.69)$ & (2.48) \\
\hline & GFEDv3 & 0.02 & 0.43 & 1.37 & 3.26 & 2.60 & 0.18 & 7.23 \\
\hline & FLAMBE & 1.34 & 4.35 & 12.86 & 11.89 & 15.31 & 1.12 & 40.06 \\
\hline \multirow[t]{5}{*}{ ANTHWUS } & A priori & 6.13 & 5.98 & 5.85 & 5.82 & 5.92 & 6.15 & 17.59 \\
\hline & A posteriori & 3.39 & 3.26 & 2.79 & 2.81 & 3.47 & 3.11 & 9.07 \\
\hline & $\left(2^{\circ} \times 2.5^{\circ}\right)$ & $(0.36)$ & $(0.27)$ & $(0.33)$ & $(0.24)$ & $(0.36)$ & $(0.38)$ & (0.94) \\
\hline & A posteriori & 3.30 & 2.96 & 3.61 & 3.07 & 4.56 & 3.95 & 11.24 \\
\hline & $\left(0.5^{\circ} \times 0.667^{\circ}\right)$ & $(0.36)$ & $(0.26)$ & $(0.31)$ & $(0.24)$ & $(0.34)$ & $(0.35)$ & $(0.89)$ \\
\hline
\end{tabular}

${ }^{*}$ Uncertainties in parentheses.

factor of 2.7). The emissions are substantially higher (by a factor of 6) in FLAMBE than in the a priori emissions. We note that the a priori emissions have the same total emissions as the original GFEDv2 emissions and are thus known to underestimate biomass burning BC emissions in the WUS (Randerson et al., 2012; Mao et al., 2011). The difference between FLAMBE and the a posteriori emissions, however, is substantially smaller. The emissions are $26 \%$ higher in FLAMBE than in the a posteriori at $2^{\circ} \times 2.5^{\circ}$. The difference is a factor of two between FLAMBE and the a posteriori at $0.5^{\circ} \times 0.667^{\circ}$. Previous studies have indicated substantial reductions to the FLAMBE inventory for Russia (53\%, Wang et al., 2011) and for Southeast Asia (45\%, Fisher et al., 2010).

\subsection{Evaluation of the a posteriori estimates with IMPROVE observations}

Figure 9 shows model simulated and observed surface BC concentrations for May-October 2006 at 10 sites in the Rockies (a-d), the Pacific Northwest (e-g), and California and the Southwest $(\mathrm{h}-\mathrm{j})$. Model results are from simulations at $2^{\circ} \times 2.5^{\circ}$ and $0.5^{\circ} \times 0.667^{\circ}$ and with the a priori and the a posteriori emissions. The a posteriori emissions significantly improve model agreement with observations, not only at individual sites (Fig. 9) but also on average over each of the aforementioned three regions (Fig. 10) and at four altitude ranges (below 1, 1-2, 2-3, and above $3 \mathrm{~km}$ ) (Fig. 11). The improvements are most pronounced for July-September, the strongest part of the fire season, reflecting the large increases 

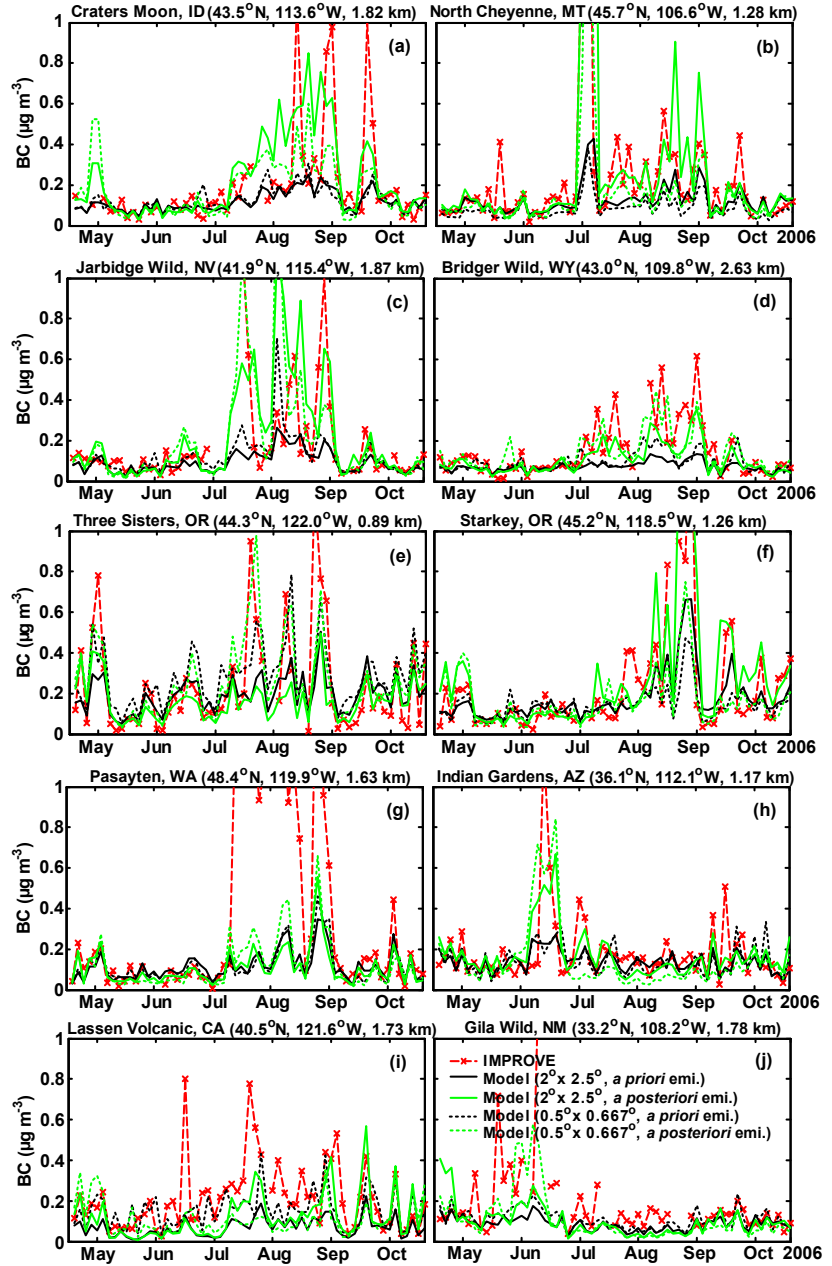

Figure 9. Observed (red line) and simulated $24 \mathrm{~h}$ average surface BC concentrations $\left(\mu \mathrm{g} \mathrm{m}^{-3}\right)$ at 10 IMPROVE sites in the Rocky Mountains (a-d), in the Pacific Northwest (e-g), and in California and the Southwest (h-j) for May-October 2006. Model results are from simulations at $2^{\circ} \times 2.5^{\circ}$ (solid line) and $0.5^{\circ} \times 0.667^{\circ}$ (dotted line) horizontal resolutions and with the a priori (black line; see Figs. 2 and 3) and a posteriori (green line) emissions.

in biomass burning emissions in the a posteriori inventory (Sect. 6.1 and Table 2). The improvements are especially evident in the Rockies and to a lesser degree in the Pacific Northwest (Fig. 10), a result of the large increases in the a posteriori biomass burning emissions in these regions. Figure 9 shows that model results with the a posteriori emissions now reproduce the observed synoptic variability in surface BC and capture the major fire episodes, for example, at Craters of the Moon, ID $\left(43.5^{\circ} \mathrm{N}, 113.6^{\circ} \mathrm{W}, 1.82 \mathrm{~km}\right)$, North Cheyenne, MT $\left(45.7^{\circ} \mathrm{N}, 106.6^{\circ} \mathrm{W}, 1.28 \mathrm{~km}\right)$, Jarbidge Wild, NV $\left(41.9^{\circ} \mathrm{N}, 115.4^{\circ} \mathrm{W}, 1.87 \mathrm{~km}\right)$, Three Sisters, OR $\left(44.3^{\circ} \mathrm{N}, 122.0^{\circ} \mathrm{W}, 0.89 \mathrm{~km}\right)$, Starkey, OR, and Indian Gardens, AZ $\left(36.1^{\circ} \mathrm{N}, 112.1^{\circ} \mathrm{W}, 1.17 \mathrm{~km}\right)$. The a posteriori emissions lead to mean bias reductions of $32 \%$ at $2^{\circ} \times 2.5^{\circ}$ and $13 \%$ at $0.5^{\circ} \times 0.667^{\circ}$ for May-October (Fig. 6). The

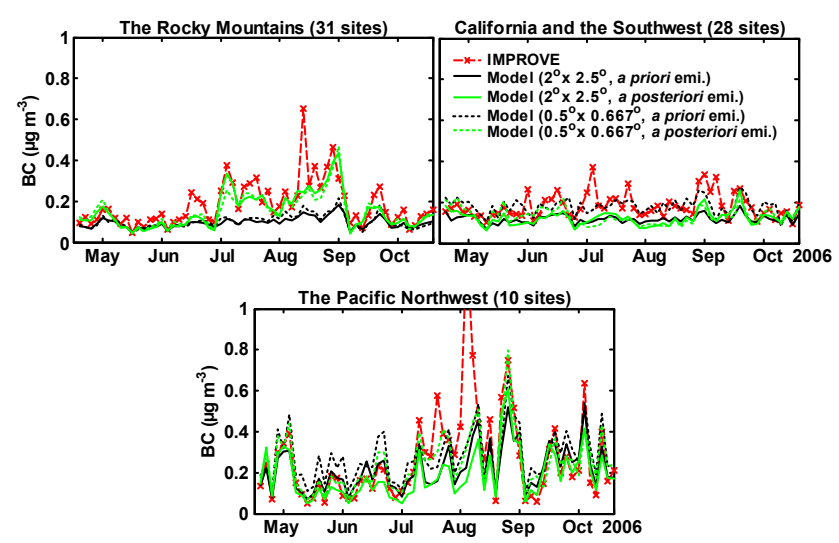

Figure 10. Observed (red line) and simulated $24 \mathrm{~h}$ average surface BC concentrations $\left(\mu \mathrm{g} \mathrm{m}^{-3}\right.$ ) averaged at IMPROVE sites in the Rockies (top left panel, 31 sites), in California and the Southwest (top right panel, 28 sites), and in the Pacific Northwest (bottom panel, 10 sites) for May-October 2006. Model results are from simulations at $2^{\circ} \times 2.5^{\circ}$ (solid line) and $0.5^{\circ} \times 0.667^{\circ}$ (dotted line) horizontal resolutions and with the a priori (black line; see Figs. 2 and 3) and a posteriori (green line) emissions.

bias reduction is $\sim 30 \%$ on average in the simulated surface $\mathrm{BC}$ concentrations at the $1-2 \mathrm{~km}$ altitude range.

Figure 12 presents the Taylor diagram (and skill scores) of our model results and the observations. The diagram provides a (visual) measure of model accuracy in comparison with observations. It relates the centered root mean square error (RMSE), the pattern correlation and the standard deviation of observations and model results (Taylor, 2001). Simulated fields are located in the first quadrant if the correlation with the reference data is positive (Gleckler et al., 2008). The Taylor skill score (ranges from 0 to 1 ) is a quantitative measure of model accuracy. It increases as the correlation becomes larger or as the modeled variance approaches the observed variance. Figure 12 shows that the a posteriori emissions increase both the average correlation coefficient ( $\sim 37 \%$ increase at both model resolutions) and the average model standard deviations $\left(45 \%\right.$ increase at $2^{\circ} \times 2.5^{\circ}$ and $26 \%$ at $0.5^{\circ} \times 0.667^{\circ}$ ), lower the centered RMSE, and increase the Taylor skill scores on average by $95 \%$ at $2^{\circ} \times 2.5^{\circ}$ and by $42 \%$ at $0.5^{\circ} \times 0.667^{\circ}$.

To investigate the robustness of our inversion results, we set aside 10 (random) IMPROVE sites and use the remaining 59 sites for our inversions. The measurements from those 10 sites are then used as independent observations for evaluating the inversions. We find that the resulting a posteriori emissions (using the aforementioned 59 sites) lead to substantial reductions $\left(\sim 30 \%\right.$ reduction at $2^{\circ} \times 2.5^{\circ}$ and $\sim 10 \%$ at $0.5^{\circ} \times 0.667^{\circ}$ ) in the mean bias of simulated surface BC concentrations averaged for the 10 sites that are not used in the inversions. The a posteriori BC emissions are essentially unchanged (within $8 \%$ at $2^{\circ} \times 2.5^{\circ}$ and $5 \%$ at $0.5^{\circ} \times 0.667^{\circ}$ ) compared with the a posteriori emissions with 69 sites. In 

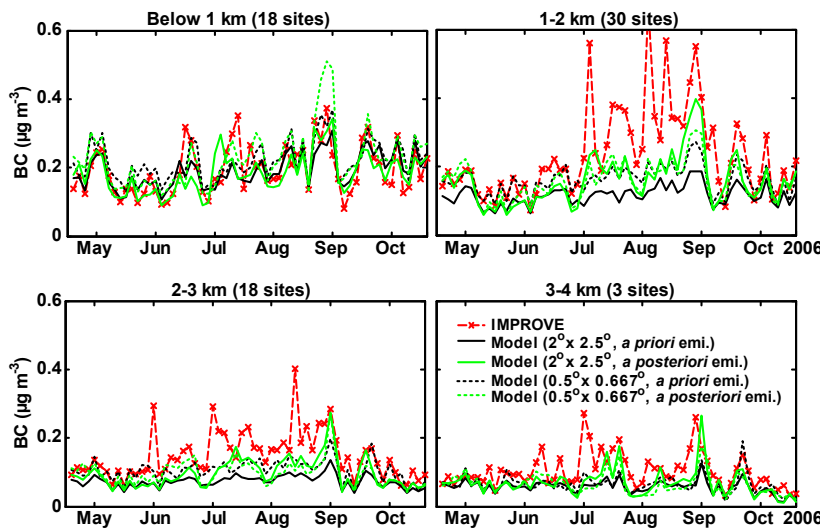

Figure 11. Same as Fig. 5, but for simulations at $2^{\circ} \times 2.5^{\circ}$ (solid line) and $0.5^{\circ} \times 0.667^{\circ}$ (dotted line) horizontal resolutions and with the a priori (black line; see Figs. 2 and 3) and a posteriori (green line) emissions.

addition, the differences in the simulated surface BC concentrations averaged at those 10 sites are rather small $(<7 \%$ at $2^{\circ} \times 2.5^{\circ}$ and $<4 \%$ at $0.5^{\circ} \times 0.667^{\circ}$ ) between the two sets (one with 59 sites and the other with 69 sites) of a posteriori BC emissions (Supplement Fig. S1).

\subsection{Sensitivity to model resolution}

In this section, we compare and contrast the a posteriori emissions and the resulting model surface $\mathrm{BC}$ concentrations at both $2^{\circ} \times 2.5^{\circ}$ and $0.5^{\circ} \times 0.667^{\circ}$ resolutions. GEOSChem simulations of surface $\mathrm{BC}$ with the a priori and a posteriori emissions are very sensitive to the model horizontal resolution. The $0.5^{\circ} \times 0.667^{\circ}$ resolution generally provides better results (compared with the observations) than the $2^{\circ} \times 2.5^{\circ}$ resolution does. This is expected because the finer resolution allows for better resolved topography, meteorological fields, transport and emissions, and therefore provides better agreement with observations, as shown in previous modeling studies (e.g., Zhang et al., 2012; Chen et al., 2009; Wang et al., 2004). The surface BC simulations at $0.5^{\circ} \times 0.667^{\circ}$ with the a priori emissions show better agreement with the observations compared with those at $2^{\circ} \times 2.5^{\circ}$, as evident in both a lower (by $44 \%$ on average, Fig. 6) model bias and a higher (by $71 \%$, Fig. 13) Taylor skill score. Inversions at $0.5^{\circ} \times 0.667^{\circ}$ also lead to larger reductions in the uncertainties of emissions, larger values of DOFs, and higher-resolution averaging kernels, compared with those at $2^{\circ} \times 2.5^{\circ}$. The resulting simulated surface $\mathrm{BC}$ concentrations at $0.5^{\circ} \times 0.667^{\circ}$ show improved agreement with observations, too. The mean biases of the simulated surface BC concentrations are $29 \%$ lower at $0.5^{\circ} \times 0.667^{\circ}$ than at $2^{\circ} \times 2.5^{\circ}$ (Fig. 6) and the corresponding Taylor skill score is higher by $24 \%$ on average (Fig. 13).

The difference in the two a posteriori biomass burning emissions (at the two resolutions) is most evident from July

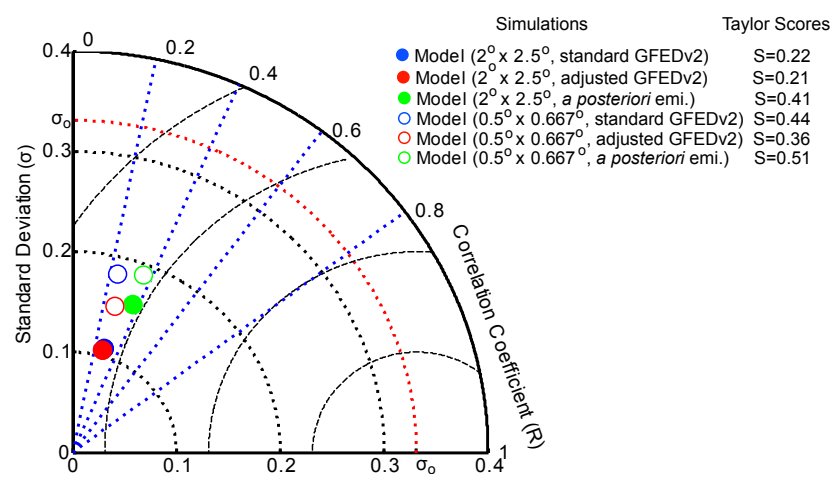

Figure 12. Taylor diagram and Taylor scores for simulations at $2^{\circ} \times 2.5^{\circ}$ (solid circle) and $0.5^{\circ} \times 0.667^{\circ}$ (open circle) horizontal resolutions and with the standard (blue circle), the adjusted (red circle; see Figs. 2 and 3) and a posteriori (green circle) emissions for May-October 2006. Values are averages for the 69 IMPROVE sites in the western US (Fig. 1).

through September 2006. The a posteriori biomass burning emissions are substantially higher (by $65 \%$ in the WUS, $48 \%$ in the RM, and nearly a factor of six in the CSW; Table 2) at $2^{\circ} \times 2.5^{\circ}$ than at $0.5^{\circ} \times 0.667^{\circ}$. In contrast, the resulting surface $\mathrm{BC}$ concentrations averaged at the IMPROVE sites are higher at the finer resolution and in better agreement with the observations. The larger discrepancies between the coarser-resolution model results and the observations to a large degree reflect the considerably larger smearing out ("dilution") of emissions at the coarse resolution than at the nested finer resolution (Chen et al., 2009). Consequently, these larger discrepancies (for the coarser-resolution model results) dictate that the inversion system, which seeks to minimize the very differences, imposes larger emissions at the coarser resolution than at the finer resolution.

\section{Summary and conclusions}

We have applied Bayesian linear inversions to derive topdown estimates of biomass burning and anthropogenic emissions of BC in the WUS for May-October 2006 by inverting surface $\mathrm{BC}$ concentrations from the IMPROVE network. We conducted analytical inversions using the GEOS-Chem chemical transport model at both $2^{\circ} \times 2.5^{\circ}$ and $0.5^{\circ} \times 0.667^{\circ}$ (nested over North America) horizontal resolutions. Model simulated surface $\mathrm{BC}$ concentrations with both the a priori and the a posteriori emissions were compared with observations.

We first used MODIS active fire counts to improve the spatiotemporal distributions of the GFEDv2 biomass burning emissions of BC. The adjustment primarily shifted emissions from late to middle and early summer (a $33 \%$ decrease in September-October and a $56 \%$ increase in JuneAugust) and led to significant enhancements in model simulated surface $\mathrm{BC}$ concentrations in early and middle summer, 
particularly evident at the $1-2$ and $2-3 \mathrm{~km}$ altitude ranges and at $0.5^{\circ} \times 0.667^{\circ}$. The adjustment also reduced the median model bias by $64 \%$ at $0.5^{\circ} \times 0.667^{\circ}$ but had little to no effect on the model bias at $2^{\circ} \times 2.5^{\circ}$. The resulting emissions were then used as the a priori for the inversions.

The examination of the averaging kernels and DOFs at both $2^{\circ} \times 2.5^{\circ}$ and $0.5^{\circ} \times 0.667^{\circ}$ indicated that the inversion system had sufficient information to uniquely constrain the four elements of the state vector and our retrievals were reliable with specified errors, especially for July-September 2006. The inversions led to large reductions in cost functions $\left(42 \%\right.$ at $2^{\circ} \times 2.5^{\circ}$ and $38 \%$ at $\left.0.5^{\circ} \times 0.667^{\circ}\right)$ and the uncertainties of the emissions $(>50 \%)$. An a priori biomass burning emissions error of $500 \%$ and a total observation error of $30 \%$ provided the best overall inversion results, with larger reductions in uncertainties, larger values of DOFs, and better-resolved averaging kernels.

The a posteriori biomass burning BC emissions for JulySeptember are $31.7 \mathrm{Gg}$ at $2^{\circ} \times 2.5^{\circ}$ (an increase by a factor of 4.7) and $19.2 \mathrm{Gg}$ at $0.5^{\circ} \times 0.667^{\circ}$ (an increase by a factor of 2.8), relative to the a priori. The corresponding a posteriori anthropogenic BC emissions were $9.1 \mathrm{Gg}$ at $2^{\circ} \times 2.5^{\circ}$ (a decrease of $48 \%$ ) and $11.2 \mathrm{Gg}$ at $0.5^{\circ} \times 0.667^{\circ}$ (a decrease of $36 \%$ ). The GFEDv3 BC emissions were higher than the a priori estimates $(8 \%)$ and lower than the a posteriori estimates (by factors of 4.4 at $2^{\circ} \times 2.5^{\circ}$ and 2.7 at $0.5^{\circ} \times 0.667^{\circ}$ ) in the WUS for July-September 2006. FLAMBE emissions were higher than the a priori emissions (by a factor of 5.9) and similar to the a posteriori emissions (factors of 1.3 at $2^{\circ} \times 2.5^{\circ}$ and 2.1 at $0.5^{\circ} \times 0.667^{\circ}$ ) in the WUS during July to September 2006. Model surface BC concentrations with the a posteriori emissions captured the major fire episodes at many IMPROVE sites, especially at the 1-2 and 2-3 km altitude ranges. The a posteriori estimates significantly improved the model agreement with observations, especially at $0.5^{\circ} \times 0.667^{\circ}$, in the Rockies, and for July-September. The a posteriori emissions substantially reduced the bias of the simulated surface BC concentrations ( $\sim 30 \%$ on average) and increased the resulting Taylor skill scores $\left(95 \%\right.$ at $2^{\circ} \times 2.5^{\circ}$ and $42 \%$ at $0.5^{\circ} \times 0.667^{\circ}$ ).

The inversion results are rather sensitive to the model horizontal resolution. The a posteriori biomass burning emissions showed large regional and month-to-month differences between the two model resolutions. The biomass burning emissions were generally lower at $0.5^{\circ} \times 0.667^{\circ}$ than at $2^{\circ} \times 2.5^{\circ}$. The large differences in the two a posteriori emissions suggested that the inversion system likely imposed larger emissions at the coarser resolution than at the finer resolution to minimize the larger differences between the coarser-resolution model results and the observations, because of the larger smearing out of emissions at the coarse resolution.

\section{The Supplement related to this article is available online at doi:10.5194/acp-14-7195-2014-supplement.}

Acknowledgements. This research was supported by NASA grant NNX09AF07G from the Atmospheric Chemistry Modeling and Analysis Program (ACMAP). The GEOS-Chem model is managed by the Atmospheric Chemistry Modeling group at Harvard University with support from the NASA ACMAP program. We thank J. Randerson, D. Henze, M. Kopacz, Z. Li, Y. Chen, L. Zhang, J. Fisher, and Q. Wang for helpful discussions. We thank three reviewers and editor for helpful suggestions and comments.

Edited by: B. N. Duncan

\section{References}

Allen, D. J., Rood, R. B., Thompson, A. M., and Hudson, R. D.: Three-dimensional ranon 222 calculations using assimilated metrological data and a convective mixing algorithm, J. Geophys. Res., 101, 6871-6881, 1996a.

Allen, D. J., Kasibhatla, P., Thompson, A. M., Rood, R. B., Doddridge, B. G., Pickering, K. E., Hudson, R. D., and Lin, S.-J.: Transport-induced interannual variability of carbon monoxide determined using a chemistry and transport model, J. Geophys. Res., 101, 28655-28669, 1996b.

Andreae, M. O. and Merlet, P.: Emission of trace gases and aerosols from biomass burning, Global Biogeochem. Cy., 15, 955-966, 2001.

Anenberg, S. C., Talgo, K., Arunachalam, S., Dolwick, P., Jang, C., and West, J. J.: Impacts of global, regional, and sectoral black carbon emission reductions on surface air quality and human mortality, Atmos. Chem. Phys., 11, 7253-7267, doi:10.5194/acp-11-7253-2011, 2011.

Anenberg, S. C., Schwartz, J., Shindell, D., Amann, M., Faluvegi, G., Klimont, Z., Janssens-Maenhout, G., Pozzoli, L., Van Dingenen, R., Vignati, E., Emberson, L., Muller, N. Z., West, J. J., Williams, M., Demkine, V., Hicks, W. K., Kuylenstierna, J., Raes, F., and Ramanathan, V.: Global air quality and health cobenefits of mitigating near-term climate change through methane and black carbon emission controls, Environ. Health Persp., 120, 831-839, 2012.

Arakawa, A. and Schubert, W. H.: Interaction of a cumulus cloud ensemble with the large-scale environment, Part I, J. Atmos. Sci., 31, 674-701, 1974.

Arellano, A. F., Kasibhatla, P. S., Giglio, L., van der Werf, G. R., and Randerson, J. T.: Top-down estimates of global CO sources using MOPITT Measurements, Geophys. Res. Lett., 31, L01104, doi:10.1029/2003GL018609, 2004.

Arellano, A. F., Kasibhatla, P. S., Giglio, L., van der Werf, G. R., Randerson, J. T., and Collatz, G. J.: Time-dependent inversion estimates of global biomass-burning CO emissions using Measurement of Pollution in the Troposphere (MOPITT) measurements, J. Geophys. Res., 111, D09303, doi:10.1029/2005JD006613, 2006.

Bergamaschi, P., Hein, R., Heimann, M., and Crutzen P. J.: Inverse modeling of the global $\mathrm{CO}$ cycle: 1 . Inversion of $\mathrm{CO}$ mixing ratios, J. Geophys. Res., 105, 1909-1927, 2000. 
Bey, I., Jacob, D. J., Yantosca, R. M., Logan, J. A., Field, B. D., Fiore, A. M., Li, Q., Liu, H.-Y., Mickley, L. J., and Schultz, M. G.: Global modeling of tropospheric chemistry with assimilated meteorology: Model description and evaluation, J. Geophys. Res., 106, 23073-23095, 2001.

Bond, T. and Sun, H.: Can Reducing Black Carbon Emissions Counteract Global Warming? Environ. Sci. Technol., 39, 59215926, 2005.

Bond, T. C., Bhardwaj, E., Dong, R., Jogani, R., Jung, S., Roden, C., Streets, D. G., and Trautmann, N. M.: Historical emissions of black and organic carbon aerosol from energy-related combustion, 1850-2000, Global Biogeochem. Cy., 21, GB2018, doi:10.1029/2006GB002840, 2007.

Bond, T. C., Doherty, S. J., Fahey, D. W., Forster, P. M., Berntsen, T., DeAngelo, B. J., Flanner, M. G., Ghan, S., Kärcher, B., Koch, D., Kinne, S., Kondo, Y., Quinn, P. K., Sarofim, M. C., Schultz, M. G., Schulz, M., Venkataraman, C., Zhang, H., Zhang, S., Bellouin, N., Guttikunda, S. K., Hopke, P. K., Jacobson, M. Z., Kaiser, J. W., Klimont, Z., Lohmann, U., Schwarz, J. P., Shindell, D., Storelvmo, T., Warren, S. G., and Zender, C. S.: Bounding the role of black carbon in the climate system: A scientific assessment, J. Geophys. Res., 118, 5380-5552, doi:10.1002/jgrd.50171, 2013.

Chen, D., Wang, Y., McElroy, M. B., He, K., Yantosca, R. M., and Le Sager, P.: Regional CO pollution and export in China simulated by the high-resolution nested-grid GEOS-Chem model, Atmos. Chem. Phys., 9, 3825-3839, doi:10.5194/acp-9-3825-2009, 2009.

Chevallier, F., Brèon, F.-M., and Rayner, P. J.: Contribution of the Orbiting Carbon Observatory to the estimation of $\mathrm{CO} 2$ sources and sinks: Theoretical study in a variational data assimilation framework, J. Geophys. Res., 112, D09307, doi:10.1029/2006JD007375, 2007.

Chin, M., Ginoux, P., Kinne, S., Torres, O., Holben, B. N., Duncan, B. N., Martin, R. V., Logan, J. A., Higurashi, A., and Nakajima, T.: Tropospheric aerosol optical thickness from the GOCART model and comparisons with satellite and sun photometer measurements, J. Atmos. Sci., 59, 461-483, 2002.

Chow, J. C., Watson, J. G., Pritchett, L. C., Pierson, W. R., Frazier, C. A., and Purcell, R. G.: The DRI thermal/optical reflectance carbon analysis system: Description, evaluation, and applications in U.S. air quality studies, Atmos. Environ., 27, 1185-1201, 1993.

Chow, J. C., Watson, J. G., Chen, L. W. A., Arnott, W. P., and Moosmuller, H.: Equivalence of elemental carbon by thermal/optical reflectance and transmittance with different temperature protocols, Environ. Sci. Technol., 38, 4414-4422, 2004.

Cooke, W. F., Liousse, C., Cachier, H., and Feichter, J.: Construction of a $1^{\circ} \times 1^{\circ}$ fossil fuel emission data set for carbonaceous aerosol and implementation and radiative impact in the ECHAM4 model, J. Geophys. Res., 104, 22137-22162, 1999.

Fairlie, T. D., Jacob, D. J., and Park, R. J.: The impact of transpacific transport of mineral dust in the United States, Atmos. Environ., 41, 1251-1266, 2007.

Fisher, J. A., Jacob, D. J., Purdy, M. T., Kopacz, M., Le Sager, P., Carouge, C., Holmes, C. D., Yantosca, R. M., Batchelor, R. L., Strong, K., Diskin, G. S., Fuelberg, H. E., Holloway, J. S., Hyer, E. J., McMillan, W. W., Warner, J., Streets, D. G., Zhang, Q., Wang, Y., and $\mathrm{Wu}, \mathrm{S} .:$ Source attribution and interannual vari- ability of Arctic pollution in spring constrained by aircraft (ARCTAS, ARCPAC) and satellite (AIRS) observations of carbon monoxide, Atmos. Chem. Phys., 10, 977-996, doi:10.5194/acp10-977-2010, 2010.

Flanner, M. G., Zender, C. S., Randerson, J. T., and Rasch, P. J.: Present-day climate forcing and response from black carbon in snow, J. Geophys. Res., 112, D11202, doi:10.1029/2006JD008003, 2007.

Flanner, M. G., Zender, C. S., Hess, P. G., Mahowald, N. M., Painter, T. H., Ramanathan, V., and Rasch, P. J.: Springtime warming and reduced snow cover from carbonaceous particles, Atmos. Chem. Phys., 9, 2481-2497, doi:10.5194/acp-9-24812009, 2009.

Fu, T.-M., Cao, J. J., Zhang, X. Y., Lee, S. C., Zhang, Q., Han, Y. M., Qu, W. J., Han, Z., Zhang, R., Wang, Y. X., Chen, D., and Henze, D. K.: Carbonaceous aerosols in China: top-down constraints on primary sources and estimation of secondary contribution, Atmos. Chem. Phys., 12, 2725-2746, doi:10.5194/acp12-2725-2012, 2012.

Fuglestvedt, J. S., Shine, K. P., Bernsten, T., Cook, J., Lee, D. S., Stenke, A., Skeie, R. B., Velders, G. J. M., and Waitz, I. A.: Transport impacts on atmosphere and climate: Metrics, Atmos. Environ., 44, 4648-4677, 2010.

Giglio, L., Descloitres, J., Justice, C. O., and Kaufman, Y.: An enhanced contextual fire detection algorithm for MODIS, Remote Sens. Environ., 87, 273-282, 2003.

Giglio, L., van der Werf, G. R., Randerson, J. T., Collatz, G. J., and Kasibhatla, P.: Global estimation of burned area using MODIS active fire observations, Atmos. Chem. Phys., 6, 957974, doi:10.5194/acp-6-957-2006, 2006.

Giglio, L., Randerson, J. T., van der Werf, G. R., Kasibhatla, P. S., Collatz, G. J., Morton, D. C., and DeFries, R. S.: Assessing variability and long-term trends in burned area by merging multiple satellite fire products, Biogeosciences, 7, 1171-1186, doi:10.5194/bg-7-1171-2010, 2010.

Gleckler, P. J., Taylor, K. E., and Doutriaux, C.: Performance metrics for climate models, J. Geophys. Res., 113, D06104, doi:10.1029/2007JD008972, 2008.

Gloor, M., Fan, S.-M., Pacala, S. W., Sarmiento, J. L., and Ramonet, M.: A model-based evaluation of inversions of atmospheric transport, using annual mean mixing ratios, as a tool to monitor fluxes of nonreactive trace substances like $\mathrm{CO}_{2}$ on a continental scale, J. Geophys. Res., 104, 14245-14260, 1999.

Hack, J. J.: Parameterization of moist convection in the NCAR community climate model (CCM2), J. Geophys. Res., 99, 55515568, doi:10.1029/93JD03478, 1994.

Hansen, J. and Nazarenko, L.: Soot climate forcing via snow and ice albedos, P. Natl. Acad. Sci. USA, 101, 423-428, 2004.

Hansen, J., Sato, M., Ruedy, R., Nazarenko, L., Lacis, A., Schmidt, G. A., Russell, G., Aleinov, I., Bauer, M., Bauer, S., Bell, N., Cairns, B., Canuto, V., Chandler, M., Cheng, Y., Del Genio, A., Faluvegi, G., Fleming, E., Friend, A., Hall, T., Jackman, C., Kelley, M., Kiang, N., Koch, D., Lean, J., Lerner, J., Lo, K., Menon, S., Miller, R., Minnis, P., Novakov, T., Oinas, V., Perlwitz, Ja. Perlwitz, Ju., Rind, D., Romanou, A., Shindell, D., Stone, P., Sun, S., Tausnev, N., Thresher, D., Wielicki, B., Wong, T., Yao, M., and Zhang, S.: Efficacy of climate forcings, J. Geophys. Res., 110, D18104, doi:10.1029/2005JD005776, 2005. 
Heald, C. L., Jacob, D. J., Jones, D. B. A., Palmer, P. I., Logan, J. A., Streets, D. G., Sachse, G. W., Gille, J. C., Hoffman, R. N., and Nehrkorn, T.: Comparative inverse analysis of satellite (MOPITT) and aircraft (TRACE-P) observations to estimate Asian sources of carbon monoxide, J. Geophys. Res., 109, D15S04, doi:10.1029/2004JD005185, 2004.

Hein, R., Crutzen, P. J., and Heimann, M.: An inverse modeling approach to investigate the global atmospheric methane cycle, Global Biogeochem. Cy., 11, 43-76, 1997.

Henze, D. K., Seinfeld, J. H., and Shindell, D. T.: Inverse modeling and mapping US air quality influences of inorganic $\mathrm{PM}_{2.5}$ precursor emissions using the adjoint of GEOS-Chem, Atmos. Chem. Phys., 9, 5877-5903, doi:10.5194/acp-9-5877-2009, 2009.

Horvath, H.: Atmospheric light absorption - A review, Atmos. Environ., 27, 293-317, 1993.

IPCC: Intergovernmental Panel on Climate Change: The Physical Science Basis, in: Contribution of Working Group I to the Fourth Assessment Report of the Intergovernmental Panel on Climate Change, edited by: Solomon, S., Qin, D., Manning, M., Chen, Z., Marquis, M., Averyt, K. B., Tignor M., and Miller, H. L., Cambridge Univ. Press, Cambridge, UK, 2007.

Jacobson, M. Z.: Strong radiative heating due to the mixing state of black carbon in atmospheric aerosols, Nature, 409, 695-697, 2001.

Jacobson, M. Z.: Control of fossil-fuel particulate black carbon and organic matter, possibly the most effective method of slowing global warming, J. Geophys. Res., 107, 4410, doi:10.1029/2001JD001376, 2002.

Jacobson, M. Z.: Climate response of fossil fuel and biofuel soot, accounting for soot's feedback to snow and sea ice albedo and emissivity, J. Geophys. Res., 109, D21201, doi:10.1029/2004JD004945, 2004.

Jacobson, M. Z.: Short-term effects of controlling fossil-fuel soot, biofuel soot and gases, and methane on climate, Arctic ice, and air pollution health, J. Geophys. Res., 115, D14209, doi:10.1029/2009JD013795, 2010.

Jaffe, D., Hafner, W., Chand, D., Westerling, A., and Spracklen, D.: Interannual variations in $\mathrm{PM}_{2.5}$ due to wildfires in the western United States, Environ. Sci. Technol., 42, 2812-2818, 2008.

Jiang, Z., Jones, D. B. A., Kopacz, M., Liu, J., Henze, D. K., and Heald, C.: Quantifying the impact of model errors on top-down estimates of carbon monoxide emissions using satellite observations, J. Geophys. Res., 116, D15306, doi:10.1029/2010JD015282, 2011.

Jiang, Z., Jones, D. B. A., Worden, H. M., Deeter, M. N., Henze, D. K., Worden, J., Bowman, K. W., Brenninkmeijer, C. A. M., and Schuck, T. J.: Impact of model errors in convective transport on $\mathrm{CO}$ source estimates inferred from MOPITT CO retrievals, J. Geophys. Res.-Atmos., 118, 2073-2083, doi:10.1002/jgrd.50216, 2013.

Jones, D. B. A., Bowman, K. W., Logan, J. A., Heald, C. L., Liu, J., Luo, M., Worden, J., and Drummond, J.: The zonal structure of tropical $\mathrm{O}_{3}$ and $\mathrm{CO}$ as observed by the Tropospheric Emission Spectrometer in November 2004 - Part 1: Inverse modeling of CO emissions, Atmos. Chem. Phys., 9, 3547-3562, doi:10.5194/acp-9-3547-2009, 2009.

Kasibhatla, P., Arellano, A., Logan, J, A., Palmer, P. I., and Novelli, P.: Top-down estimate of a large source of atmospheric carbon monoxide associated with fuel combustion in Asia, Geophys. Res. Lett.,29, L191900, doi:10.1029/2002GL015581, 2002.

Kasischke, E. S., Hewson, J. H., Stocks, B., van der Werf, G., and Randerson, J.: The use of ATSR active fire counts for estimating relative patterns of biomass burning - a study from the boreal forest region, Geophys. Res. Lett., 30, 1969, doi:10.1029/2003GL017859, 2003.

Kopacz, M., Jacob, D. J., Henze, D. K., Heald, C. L., Streets, D. G., and Zhang, Q.: Comparison of adjoint and analytical Bayesian inversion methods for constraining Asian sources of carbon monoxide using satellite (MOPITT) measurements of CO columns, J. Geophys. Res., 114, D04305, doi:10.1029/2007JD009264, 2009.

Kopacz, M., Mauzerall, D. L., Wang, J., Leibensperger, E. M., Henze, D. K., and Singh, K.: Origin and radiative forcing of black carbon transported to the Himalayas and Tibetan Plateau, Atmos. Chem. Phys., 11, 2837-2852, doi:10.5194/acp-11-28372011, 2011.

Kopp, R. E. and Mauzerall, D. L.: Assessing the climatic benefits of black carbon mitigation, P. Natl. Acad. Sci. USA, 26, 11703 11708, 2010.

Korontzi, S., McCarty, J., Loboda, T., Kumar, S., and Justice, C.: Global distribution of agricultural fires in croplands from 3 years of Moderate Resolution Imaging Spectroradiometer (MODIS) data, Global Biogeochem. Cy., 20, GB2021, doi:10.1029/2005GB002529, 2006.

Langmann, B., Duncan, B., Textor, C., Trentmann, J., and van der Werf, G. R.: Vegetation fire emissions and their impact on air pollution and climate, Atmos. Environ., 43, 107-116, 2009.

Levy II, H., Schwarzkopf, M. D., Horowitz, L., Ramaswamy, V., and Findell, K. L.: Strong sensitivity of late 21 st century climate to projected changes in short-lived air pollutants, J. Geophys. Res., 113, D06102, doi:10.1029/2007JD009176, 2008.

Lin, S.-J. and Rood, R. B.: Multidimensional flux-form semiLagrangian transport schemes, Mon. Weather Rev., 124, 20462070, 1996.

Liu, H., Jacob, D. J., Bey, I., and Yantosca, R. M.: Constraints from ${ }^{210} \mathrm{~Pb}$ and ${ }^{7} \mathrm{Be}$ on wet deposition and transport in a global threedimensional chemical tracer model driven by assimilated meteorological fields, J. Geophys. Res., 106, 12109-12128, 2001.

Lu, Z., Zhang, Q., and Streets, D. G.: Sulfur dioxide and primary carbonaceous aerosol emissions in China and India, 1996-2010, Atmos. Chem. Phys., 11, 9839-9864, doi:10.5194/acp-11-98392011, 2011.

Mao, Y. H., Li, Q. B., Zhang, L., Chen, Y., Randerson, J. T., Chen, D., and Liou, K. N.: Biomass burning contribution to black carbon in the Western United States Mountain Ranges, Atmos. Chem. Phys., 11, 11253-11266, doi:10.5194/acp-1111253-2011, 2011.

Malm, W. C., Sisler, J. F., Huffman, D., Eldred, R. A., and Cahill, T. A.: Spatial and seasonal trends in particle concentration and optical extinction in the United States, J. Geophys. Res., 99, 13471370, 1994.

Meirink, J. F., Bergamaschi, P., and Krol, M. C.: Fourdimensional variational data assimilation for inverse modelling of atmospheric methane emissions: method and comparison with synthesis inversion, Atmos. Chem. Phys., 8, 6341-6353, doi:10.5194/acp-8-6341-2008, 2008. 
McCarty, J. L., Korontzi, S., Justice, C. O., and Loboda, T.: The spatial and temporal distribution of crop residue burning in the contiguous United States, Sci. Total Environ., 407, 5701-5712, doi:10.1016/j.scitotenv.2009.07.009, 2009.

Mirchi, A., Madani, K., Roos, M., and Watkins, D. W.: Climate Change Impacts on California's Water Resources, Drought in Arid and Semi-Arid Regions: A Multi-Disciplinary and CrossCountry Perspective, Springer, the Netherlands, 24, 301-319, 2013.

Moorthi, S. and Suarez, M. J.: Relaxed Arakawa-Schubert: A parameterization of moist convection for general circulation models, Mon. Weather Rev., 120, 978-1002, 1992.

Murphy, D. M., Chow, J. C., Leibensperger, E. M., Malm, W. C., Pitchford, M., Schichtel, B. A., Watson, J. G., and White, W. H.: Decreases in elemental carbon and fine particle mass in the United States, Atmos. Chem. Phys., 11, 4679-4686, doi:10.5194/acp-11-4679-2011, 2011.

Müller, J.-F. and Stavrakou, T.: Inversion of $\mathrm{CO}$ and $\mathrm{NO}_{\mathrm{x}}$ emissions using the adjoint of the IMAGES model, Atmos. Chem. Phys., 5, 1157-1186, doi:10.5194/acp-5-1157-2005, 2005.

Painter, T. H., Flanner, M. G., Kaser, G., Marzeion, B., VanCuren, R. A., and Abdalati, W.: End of the Little Ice Age in the Alps forced by industrial black carbon, P. Natl. Acad. Sci. USA, 110, 15216-15221, 2013.

Palmer, P. I., Jacob, D. J., Jones, D. B. A., Heald, C. L., Yantosca, R. M., Logan, J. A., Sachse, G. W., and Streets, D. G.: Inverting for emissions of carbon monoxide from Asia using aircraft observations over the western Pacific, J. Geophys. Res., 108, 8828, doi:10.1029/2003JD003397, 2003.

Palmer, P. I., Suntharalingam, P., Jones, D. B. A., Jacob, D. J., Streets, D. G., Fu, Q. Y., Vay, S. A., and Sachse, G.: W. Using $\mathrm{CO}_{2}$ : $\mathrm{CO}$ correlations to improve inverse analyses of carbon fluxes, J. Geophys. Res., 111, D12318, doi:10.1029/2005JD006697, 2006.

Park, R. J., Jacob, D. J., Chin, M., and Martin, R. V.: Sources of carbonaceous aerosols over the United States and implications for natural visibility, J. Geophys. Res., 108, D124355, doi:10.1029/2002JD003190, 2003.

Peterson, D. L. and Marcinkowski, K. W.: Recent Changes in Climate and Forest Ecosystems, Climate Change and United States Forests, Springer, the Netherlands, 57, 3-11, 2014.

Pickett-Heaps, C. A., Rayner, P. J., Law, R. M., Ciais, P., Patra, P. K., Bousquet, P., Peylin, P., Maksyutov, S., Marshall, J., Rödenbeck, C., Langenfelds, R. L., Steele, L. P., Francey, R. J., Tans, P., and Sweeney, C.: Atmospheric $\mathrm{CO}_{2}$ inversion validation using vertical profile measurements: Analysis of four independent inversion models, J. Geophys. Res., 116, D12305, doi:10.1029/2010JD014887, 2011.

Qian, Y., Gustafson Jr., W. I., Leung, L. R., and Ghan, S. J.: Effects of soot-induced snow albedo change on snowpack and hydrological cycle in western United States based on Weather Research and Forecasting chemistry and regional climate simulations, J. Geophys. Res., 114, D03108, doi:10.1029/2008JD011039, 2009.

Ramanathan, V. and Carmichael, G.: Global and regional climate changes due to black carbon, Nat. Geosci., 1, 221-227, 2008.

Ramana, M. V., Ramanathan, V., Feng, Y., Yoon, S.-C., Kim, S.-W., Carmichael, G. R., and Schauer, J. J.: Warming influenced by the ratio of black carbon to sulphate and the black-carbon source, Nat. Geosci., 3, 542-545, 2010.
Randerson, J. T., van der Werf, G. R., Giglio, L., Collatz, G. J., and Kasibhatla, P. S.: Global Fire Emissions Database, Version 2 (GFEDv2), http://daac.ornl.gov/ (last access: 2013), Oak Ridge National Laboratory Distributed Active Archive Center, Oak Ridge, Tennessee, USA, 2007.

Randerson, J. T., Chen, Y., van der Werf, G. R., Rogers, B. M., and Morton, D. C.: Global burned area and biomass burning emissions from small fires, J. Geophys. Res., 117, G04012, doi:10.1029/2012JG002128, 2012.

Rao, V. and Somers, J. H.: Black Carbon as a Short-Lived Climate Forcer: A Profile of Emission Sources and Co-Emitted Pollutants, 19th Annual International Emission Inventory Conference, San Antonio, Texas, September, 2010.

Reddy, M. S. and Boucher, O.: Climate impact of black carbon emitted from energy consumption in the world's regions, Geophys. Res. Lett., 34, L11802, doi:10.1029/2006GL028904, 2007.

Reid, J. S., Hyer, E. J., Prins, E. M., Westphal, D. L., Zhang, J., Wang, J., Christopher, S. A., Curtis, C. A., Schmidt, C. C., Eleuterio, D. P., Richardson, K. A., and Hoffman, J. P.: Global monitoring and forecasting of biomass-burning smoke: Description and lessons from the Fire Locating and Modeling of Burning Emissions (FLAMBE) program, IEEE J. Sel. Top. Appl., 2, 144162, doi:10.1109/JSTARS.2009.2027443, 2009.

Rodgers, C. D.: Inverse Methods for Atmospheric Sounding : Theory and Practice, World Sci., Singapore, 2000.

Roy, D. P. and L. Boschetti, Southern Africa validation of the MODIS, L3JRC, and GlobCarbon burned-area products, IEEE T. Geosci. Remote, 47, 1032-1044, doi:10.1109/TGRS.2008.2009000, 2009.

Shindell, D. T., Levy II, H., Schwarzkopf, M. D., Horowitz, L. W., Lamarque, J.-F., and Faluvegi, G.: Multimodel projections of climate change from short-lived emissions due to human activities, J. Geophys. Res., 113, D11109, doi:10.1029/2007JD009152, 2008.

Shindell, D. T., Kuylenstierna, J. C. I., Vignati, E., van Dingenen, R., Amann, M., Klimont, Z., Anenberg, S. C., Muller, N., Janssens-Maenhout, G., Raes, F., Schwartz, J., Faluvegi, G., Pozzoli, L., Kupiainen, K., Höglund-Isaksson, L., Lisa Emberson, L., Streets, D., Ramanathan, V., Hicks, K., Kim Oanh, N. T., George Milly, G., Martin Williams, M., Demkine, V., and Fowler, D.: Simultaneously mitigating near-term climate change and improving human health and food security, Sciences, 335, 183-189, 2012.

Smith, K. R., Jerrett, M., Anderson, H. R., Burnett, R. T., Stone, V., Derwent, R., Atkinson, R. W., Cohen, A., Shonkoff, S. B., Krewski, D., Pope III, C. A., Thun, M. J., and Thurston, G.: Public health benefits of strategies to reduce greenhouse-gas emissions: health implications of short-lived greenhouse pollutants, Lancet, 374, 2091-2103, 2009.

Spracklen, D. V., Mickley, L. J., Logan, J. A., Hudman, R. C., Yevich, R., Flannigan, M. D., and Westerling, A. L.: Impacts of climate change from 2000 to 2050 on fire activity and carbonaceous aerosol concentrations in the western United States, J. Geophys. Res., 114, D20301, doi:10.1029/2008JD010966, 2009.

Streets, D. G., Gupta, S., Waldhoff, S. T., Wang, M. Q., Bond, T. C., and Bo, Y.: Black carbon emissions in China, Atmos. Environ., 35, 4281-4296, 2001.

Streets, D. G., Bond, T. C., Carmichael, G. R., Fernandes, S. D., Fu, Q., He, D., Klimont, Z., Nelson, S. M., Tsai, N. Y., Wang, M. 
Q., Woo, J.-H., and Yarber, K. F.: An inventory of gaseous and primary aerosol emissions in Asia in the year 2000, J. Geophys. Res., 108, D218809, doi:10.1029/2002JD003093, 2003.

Stavrakou, T. and Müller, J.-F.: Grid-based versus big region approach for inverting $\mathrm{CO}$ emissions using Measurement of Pollution in the Troposphere (MOPITT) data, J. Geophys. Res., 111, D15304, doi:10.1029/2005JD006896, 2006.

Taylor, K. E.: Summarizing multiple aspects of model performance in a single diagram, J. Geophys. Res., 106, 7183-7192, 2001.

van der Werf, G. R., Randerson, J. T., Giglio, L., Collatz, G. J., Kasibhatla, P. S., and Arellano Jr., A. F.: Interannual variability in global biomass burning emissions from 1997 to 2004, Atmos. Chem. Phys., 6, 3423-3441, doi:10.5194/acp-6-3423-2006, 2006.

van der Werf, G. R., Randerson, J. T., Giglio, L., Collatz, G. J., Mu, M., Kasibhatla, P. S., Morton, D. C., DeFries, R. S., Jin, Y., and van Leeuwen, T. T.: Global fire emissions and the contribution of deforestation, savanna, forest, agricultural, and peat fires (19972009), Atmos. Chem. Phys., 10, 11707-11735, doi:10.5194/acp10-11707-2010, 2010.

Vano, J. A., Udall, B., Cayan, D. R., Overpeck, J. T., Brekke, L. D., Das, T., and Lettenmaier, D. P.: Understanding uncertainties in future Colorado River streamflow, B. Am. Meteorol. Soc., 95, 59-78, doi:10.1175/BAMS-D-12-00228.1, 2013.

Walcek, C. J., Brost, R. A., and Chang, J. S.: $\mathrm{SO}_{2}$, sulfate and HNO3 deposition velocities computed using regional landuse and meteorological data, Atmos. Environ., 20, 949-964, 1986.

Wang, Q., Jacob, D. J., Fisher, J. A., Mao, J., Leibensperger, E. M., Carouge, C. C., Le Sager, P., Kondo, Y., Jimenez, J. L., Cubison, M. J., and Doherty, S. J.: Sources of carbonaceous aerosols and deposited black carbon in the Arctic in winter-spring: implications for radiative forcing, Atmos. Chem. Phys., 11, 1245312473, doi:10.5194/acp-11-12453-2011, 2011.

Wang, X., Wang, Y., Hao, J., Kondo, Y., Irwin, M., Munger, J. W., and Zhao, Y.: Top-down estimate of China's black carbon emissions using surface observations: Sensitivity to observation representativeness and transport model error, J. Geophys. Res. Atmos., 118, 5781-5795, doi:10.1002/jgrd.50397, 2013.
Wang, Y., McElroy, M. B., Jacob, D., and Yantosca, R. M.: A nested grid formulation for chemical transport over Asia: applications to CO, J. Geophys. Res., 109, D22307, doi:10.1029/2004JD005237, 2004.

Warren, S. G. and Wiscombe, W. J.: A model for the spectral albedo of snow. II: snow containing atmospheric aerosols, J. Atmos. Sci., 37, 2734-2745, 1980.

Wecht, K. J., Jacob, D. J., Wofsy, S. C., Kort, E. A., Worden, J. R., Kulawik, S. S., Henze, D. K., Kopacz, M., and Payne, V. H.: Validation of TES methane with HIPPO aircraft observations: implications for inverse modeling of methane sources, Atmos. Chem. Phys., 12, 1823-1832, doi:10.5194/acp-12-1823-2012, 2012.

Westerling, A. L., Hidalgo, H. G., Cayan, D. R., and Swetnam, T. W.: Warming and earlier spring increase western U.S. forest fire activity, Science, 313, 940-943, DOI: 10.1126/science.1128834, 2006.

Xu, B., Cao, J., Hansen, J., Yao, T., Joswia, D. R., Wang, N., and He, J.: Black soot and the survival of Tibetan glaciers, P. Natl. Acad. Sci., 106, 22114-22118, 2009.

Yue, X., Mickley, L. J., Logan, J. A., and Kaplan, J. O.: Ensemble projections of wildfire activity and carbonaceous aerosol concentrations over the western United States in the mid-21st century, Atmos. Environ., 77, 767-780, 2013.

Zhang, Y., Jaeglé, L., van Donkelaar, A., Martin, R. V., Holmes, C. D., Amos, H. M., Wang, Q., Talbot, R., Artz, R., Brooks, S., Luke, W., Holsen, T. M., Felton, D., Miller, E. K., Perry, K. D., Schmeltz, D., Steffen, A., Tordon, R., Weiss-Penzias, P., and Zsolway, R.: Nested-grid simulation of mercury over North America, Atmos. Chem. Phys., 12, 6095-6111, doi:10.5194/acp12-6095-2012, 2012.

Zwally, H. J., Abdalati, W., Herring, T., Larson, K., Saba, J., and Steffen, K.: Surface melt-induced acceleration of Greenland icesheet flow, Science, 297, 218-222, 2002. 